Research article

urn:1sid:zoobank.org:pub:2F526459-E23A-458B-9829-31F4C1BC6C46

\title{
The Leiobunum rupestre species group: resolving the taxonomy of four widespread European taxa (Opiliones: Sclerosomatidae)
}

\author{
Jochen MARTENS ${ }^{1, *} \&$ Axel L. SCHÖNHOFER ${ }^{2}$ \\ 1,2 Johannes Gutenberg-Universität Mainz, Institut für Zoologie, 55099 Mainz, Germany \\ *Corresponding author: martens@uni-mainz.de \\ ${ }^{2}$ Email: $\underline{\text { Axel.Schoenhofer@gmx.net }}$ \\ ${ }^{1}$ urn:Isid:zoobank.org:author:F01C78F1-5EBF-48E8-B37E-634DF00E0237 \\ ${ }^{2}$ urn:Isid:zoobank.org:author:91B2971C-D8CE-4F98-903F-C963E83E8C7C
}

\begin{abstract}
Within the central European opilionid fauna the widely used species names Leiobunum rupestre Herbst, 1799 and Leiobunum tisciae Avram, 1968 pose taxonomic and distributional problems. In addition, Nelima apenninica Martens, 1969 is close to L. tisciae in terms of external and genital morphology, but is specifically distinct. While coxal denticulation is largely lacking in $N$. apenninica, the validity of the genus Nelima Roewer, 1910 is questioned again. In addition, Leiobunum subalpinum Komposch, 1998 , a recently described novelty from the eastern Alps, is closely related to L. rupestre. The four species are combined as the morphologically defined Leiobunum rupestre species group. Except for L. subalpinum, they were found to be allopatrically distributed from the Carpathians across central and Northwest Europe to the south-western Alps. The latter species is locally sympatric and partly elevationally parapatric to L. rupestre. Leiobunum tisciae is a recently introduced name and here recognized as a junior synonym of a number of taxa described much earlier, of which $L$. gracile Thorell, 1876 is re-introduced as oldest available name. Detailed morphological and distributional data for all taxa are presented.
\end{abstract}

Keywords. Taxonomy, synonymy, Leiobunum, Nelima, Europe.

Martens J. \& Schönhofer A.L. 2016. The Leiobunum rupestre species group: resolving the taxonomy of four widespread European taxa (Opiliones: Sclerosomatidae). European Journal of Taxonomy 216: 1-35. http://dx.doi. org/10.5852/ejt.2016.216

\section{Introduction}

A common problem with the Sclerosomatidae Simon, 1879 (harvestmen) is their morphological plasticity as well as their general uniformity, making it often difficult to draw well-recognizable species borders. Even more problematic, especially in the tropics, is the differentiation of higher taxonomic levels from species category upwards (Hedin et al. 2012). Applying this difficulty to widespread, closely related and morphologically similar taxa can further hinder discrimination. Here the similar species Leiobunum rupestre (Herbst, 1799), L. subalpinum Komposch, 1998, L. tisciae Avram, 1968 and Nelima apenninica Martens, 1969 are investigated and summarized as the Leiobunum rupestre species group, though being 
generally grouped with two different genera. The four species occupy large parts of central and southeastern Europe, parts of Scandinavia (Finland, Norway, Sweden), locally Great Britain, continental Italy and south-western France, but sympatric occurrences are unknown (Fig. 2), except for L. subalpinum whose distribution is nested within the area of $L$. rupestre. Discrimination of $L$. rupestre and $L$. tisciae has been under debate since Martens (1978) included L. tisciae into the central European fauna, even though male genital morphology was properly described and is straightforward. A number of European countries stated the presence of one or two of these species thereafter (e.g., Great Britain: Davidson 2009; Denmark: Enghoff 1988; Czech Republic and Slovak Republic: Šilhavý 1981; Italy: Chemini 1980; Marcellino 1971; Poland: Staręga 2004; Norway: Stol 2003, 2010a, b; Estonia: Staręga 1978; Tomasson et al. 2014; Latvia: Tumšs 1963; Spungis 2008), but a complex morphological and taxonomic situation was evident.

The description of L. tisciae by Avram (1968) was shortly followed by that of Nelima apenninica by Martens (1969), who soon recognized that both species are fairly similar in terms of genital morphology, but he was primarily concerned to discriminate Leiobunum rupestre against L. tisciae (Martens 1978). Up to today, $N$. apenninica remains poorly known, being recorded from widely scattered localities. These four species raise taxonomic problems and need to be well defined. L. tisciae and N. apenninica having been described relatively recently, and especially because $L$. tisciae spans a large European area, making it likely that it has been described under an older name before. L. subalpinum, a novelty from the eastern Alps, added a further complexity to species recognition in this group of locally common long-legged harvestmen. Taking this argumentation into account and based on representative reference material, we here revalidate the species status, synonymy and distribution of the representatives of the L. rupestre species group. The taxa Leiobunum nigripalpe Simon, 1879 and "Leiobunum sp.", the latter a recent immigrant to western central Europe (Wijnhoven et al. 2006), are not part of the L. rupestre species group and are not treated here.

\section{Material and methods}

Material investigated: 54 series of L. rupestre, 40 series of $L$. tisciae and 20 series of $N$. apenninica were checked; details are listed in the Material sections (see Appendix). Also literature sources, which we feel present reliable records, are listed there.

\section{Collection acronyms as used:}

SMNH = Naturhistoriska riksmuseet, Stockholm, Sweden

AXLS = Coll. Axel Schönhofer, Mainz, Germany

CIK = Coll. Ivo Karaman, Novi Sad, Serbia

$\mathrm{CJM}=$ Coll. Jochen Martens, Mainz, Germany

SMF = Arachnology Section, Senckenberg Museum, Gesellschaft für Naturforschung, Frankfurt am Main, Germany

\section{Abbreviations used in the descriptive parts:}

$\begin{array}{ll}\text { Abd, abd } & =\text { Abdomen, abdominal } \\ \mathrm{Ceph} & =\text { cephalothorax } \\ \mathrm{Fe} & =\text { femur } \\ \mathrm{Mt} & =\text { metatarsus } \\ \mathrm{Palp} & =\text { palpus, pedipalpus } \\ \mathrm{Pt} & =\text { patella } \\ \mathrm{Ta} & =\text { tarsus } \\ \mathrm{Terg} & =\text { tergit } \\ \text { thorac } & =\text { thoracic }\end{array}$


$\mathrm{Ti}=$ tibia

To oc $=$ tuber oculorum, ocularium, eye mound

Original line drawings were produced using a camera lucida attached to a Leitz dissecting Microscope and a Leitz Laborlux Microscope. Measurements were taken by means of a micrometer disc using the same optical devices. All measurements are given in $\mathrm{mm}$.

\title{
Distributional data
}

From a total of 2600 text-recognized pdf files of opilionid literature, those matching the search strings 'apenninica', 'rupestre' or 'tisciae' were selected. Following our established synonymy further, references were extracted manually and all identifiable distributional records of the L. rupestre group were georeferenced. Of these records only a limited number of the recorded specimens was available to us and geographic reconstructions relied on our representative samplings and sound publication data. We assume Šilhavý (1981) and Staręga $(1976,2004)$ to have correctly discriminated L. rupestre and L. 'tisciae' (L. glabrum in Šilhavý 1981) and their data already demarked a North-to-South running borderline between the two species in the Czech Republic and Slovakia (Šilhavý 1981) and in Poland (Staręga 2004). We further interpreted all records east of this line (e.g., L. rupestre in Staręga 1978) and north of the central mountain ranges in Germany (e.g., Stol 2010a, b) as L. 'tisciae', primarily based on investigation of available material. If we found coverage of records sufficiently reliable and indicative of general distributional interpretation we did not map additional records in the relevant area (for these, see in more detail: L. tisciae: Denmark: Meinertz 1964; Enghoff 1988; Great Britain: British Arachnological Society 2016; L. rupestre and tisciae combined: Germany: Staudt 2016). All reconstructed localities are given in Fig. 2 and Appendix 1. Up to-date distributional data of Leiobunum subalpinum was available from Komposch $(1998,2009 b)$ and we did not search for any additional records.

\section{Results}

\author{
Class Arachnida Cuvier, 1812 \\ Order Opiliones Sundevall, 1833 \\ Suborder Palpatores Thorell, 1876 \\ Family Sclerosomatidae Simon, 1879 \\ Subfamily Leiobuninae Banks, 1893 \\ Genus Leiobunum C.L. Koch, 1839
}

\section{Type species}

Designation by Thorell, 1876: Opilio fasciatus Herbst, 1798 = Leiobunum rotundum (Latreille, 1798).

\section{Remark}

Of the representative material investigated, we found the four hypothesized species well separable upon a number of somatic and male genital morphological characters, which are summarized in Table 1 for convenient use. Species appear largely allopatric, except for $L$. subalpinum, which is firmly nested within the area of $L$. rupestre. In addition, parapatric and locally sympatric occurrences of two species under discussion in East-Central Europe cannot be excluded, especially in South Poland, the central Alps and close to the Czech/Slovak border area (Fig. 2).

Leiobunum subalpinum Komposch, 1998 is considered most closely related to L. rupestre (Komposch 1998) and, as such, is also regarded as a member of the L. rupestre species group. As it is easily discriminated from all discussed forms by its dark coxal markings and, apart from L. rupestre, by its restricted alpine range, it is not featured here (see Komposch 1998; Komposch \& Gruber 2004 for 
Table 1. Comparison of somatic characters of Leiobunum apenninicum (Martens, 1969), L. gracile Thorell, 1876 and L. rupestre Herbst, 1799. L. subalpinum Komposch, 1998 is not included, because it is very similar to L. rupestre and is easily identified by its black coxal markings. For comparison with $L$. rupestre we refer to Komposch (1998). If not otherwise mentioned, characters apply to males only. Characters outlining a single species are given in bold, more variable characters are given in italics. The combination of several characters for determination is advised. Palpal spination is variable, apparently the appearance in ordered rows is an individual character. Body coloration varies with age and population, aged specimens are darkest.

L. rupestre Herbst, $1799 \quad$ L. gracile Thorell, $1876 \quad$ L. apenninicum (Martens, 1969)

in both sexes dorsum smooth, granulation cannot be distinguished with $250 \times$, with a few pointed granules present

palp-femur with irregular rows of medium-sized triangular spines on ventral side; dorsal side few on distal part, ventral spines more slender, many pointing downward

palp-tibia slightly concave in lateral view at ventro-distal end, therefore forming a flat S-bend

palp-patella appears longer and less massive

palp-tarsus bent over its whole length

denticles and hairs on ventral side of palp-tibia darker and therefore well visible

eye mound in both sexes always without spines

in both sexes dorsal coloration without pair of white spots on each area along the median line area along the median line

in females no lateral coloration of opisthosoma with a blurred parallel pattern of zigzag lines palp-femur with irregular rows

of large triangular spines on ventral side; dorsal side few on distal part, ventral spines broader, not so slender

palp-tibia slightly concave at ventro-distal end, therefore

forming a flat S-bend

palp-patella appears longer and less massive

palp-tarsus mostly straight, bent only in distal third

spines and hairs on ventral side of palp-tibia lighter and therefore hard to be seen

eye mound in both sexes without spines, sometimes one spine present

in both sexes dorsal coloration with small white spots on each in females lateral coloration of opisthosoma with a blurred parallel pattern of zigzag lines, best seen at low magnification in both sexes dorsal granulation consisting of flat, pointed granules, regularly spaced, well visible at $250 \times$

palp-femur with few spines, normally restricted to ventrodistal, rarely few large spines on ventral side, only single spines on dorso-distal side

palp-tibia not concave at ventro-distal end, therefore forming a flat $\mathrm{C}$-bend

\section{palp-patella appears shorter and more massive}

palp-tarsus bent over its whole length

spines and hairs on ventral side of palp-tibia lighter and therefore hard to be seen

eye mound in both sexes with 1-3 small spines on each side, rarely absent

in both sexes dorsal coloration with pair of white spots on each area along the median line

in females lateral coloration of opisthosoma with a blurred parallel pattern of zigzag lines, best seen at low magnification 
details) except for general remarks; its geographic range is indicated in Fig. 2. In addition, the poorly known Leiobunum nigripalpe Simon, 1889, described from the western Alps (France), was reinvestigated. However, the type series represents a composite collection of at least two different small Nelima Roewer species, both unaffiliated to the L. rupestre species group. This holds true, too, for the specimen depicted as Leiobunum nigripalpe in Martens (1978), representing a yet to be identified Leiobunum species.

\section{Species accounts of the Leiobunum rupestre group}

Leiobunum rupestre (Herbst, 1799)

Figs $1 \mathrm{~A}-\mathrm{B}, 2$, 3A-B, 4A-B, H-G, 5A-C

Phalangium bicolor Fabricius, 1793: 429. The name was synonymized with Gyas annulatus by Latreille (1804), which was missed by several subsequent authors; some of these used it as valid name, in synonymy of, or in relation to, L. rupestre (e.g., C.L. Koch 1847, 16: 56; redescription).

Opilio rupestris Herbst, 1799: 4, fig. 1 (material from the type locality Sachsen, i.e., Saxony, examined). Leiobunum ovale C.L. Koch, 1848: 59, fig. 1540.

Liobunum glabrum L. Koch, 1869: 4, 6-7.

Leiobunum ovale - Roewer 1910: 203. — Šilhavý 1956: 174. — Novak \& Gruber 2000: 299.

Phalangium bicolor - Simon 1879: 181. — Roewer 1910: 203 (both also listing Phalangium annulatum in synonymy). — Lessert 1917: 16.

Liobunum rupestre - Simon 1879: 181. — Cantoni 1882: 194. — Hansen 1884: 500. — Kraepelin 1896: 222. — Roewer 1910: 197, 203. — Lessert 1917: 15. — Roewer 1923: 890 (partim). — Hadži 1931: 145. — Šilhavý 1956: 174, figs 437-443.

Liobunus rupestris - Müller \& Schenkel 1895: 819.

Liobunum glabrum - Simon 1879: 181.

Nelima glabra - Roewer 1910: 239. — Hadži 1931: 148.

Leiobunum rupestre - Šilhavý 1948: 9, 24, table 6, figs 4-6. — Martens 1978: 408-412, figs 778-780, 788. - Komposch 1998: 26-27, 34, figs 5, 10, 14, 21.

\section{Taxonomic history}

At first glance rather complex, but many distributional records from East central, Northwest and North Europe in reality refer to Leiobunum 'tisciae' (see below, L. gracile). L. rupestre is a montane species and well known from low to mid-altitudes of the central and eastern Alps and mountainous areas in the Czech Republic and north of the Alps in Germany. Its genital morphology is quite characteristic and was first reliably depicted by Šilhavý (1948, figs 4-6; 1956, figs 437-439), fully in accordance with drawings in Martens (1978, fig. 778) and Komposch (1998, figs 9-10). Leiobunum populations in the Carpathians, Poland (Staręga 1976), southern Finland (Heinäjoki 1944), along the Baltic coast hinterland and Denmark were also largely affiliated to L. rupestre (Martens 1978, fig. 787), though erroneously. These older determinations mostly neglected the genital morphology of these crucial northern populations, which was reconsidered after Avram (1968) published a new species, L. tisciae, clearly distinct from rupestre but similar in external morphology. Due to its wide distribution, the majority of available names for the eastern and northern populations can be assigned to the synonym of its oldest name L. gracile (see below).

Excluding the complex synonymy of L. tisciae (gracile), only one uncertain affiliation remains for L. rupestre: the name Liobunum glabrum L. Koch, 1869. Šilhavý (1956: fig. 443) originally treated 'glabra' as the juvenile $L$. rupestre, but later used this name to distinguish allopatric populations of western L. rupestre and eastern L. 'glabra' (later named L. tisciae) in former Czechoslovakia (Šilhavý 
1981). This was contradicted by Staręga (2004), because the type locality of L. glabrum, Meran (northern Italy, southern Alps), is situated deeply within the territory of L. rupestre (Martens 1978). We suggest following Hadži (1931) and Martens (1978) to correctly place Leiobunum glabrum in the synonymy of L. rupestre.

\section{Diagnosis}

A medium-sized Leiobunum species with blackish upper side, except for broad, white markings on Ceph disto-laterally in male (Figs 1A, 3A), broad, blackish irregular saddle-like marking all over the length of the body in female with extended white markings laterally from Ceph to abd Area II and a cross stripe all over area V (Figs 1B, 3B). In both sexes series of para-median lines of small white spots on the abd areae $\mathrm{I}-\mathrm{V}$ are absent. Contrasting yellowish underside including coxae of all appendages. Wings of truncus penis broad, broadest in lower third part of truncus (Fig. 5A-B). Coxa IV with retrolateral row of granules.
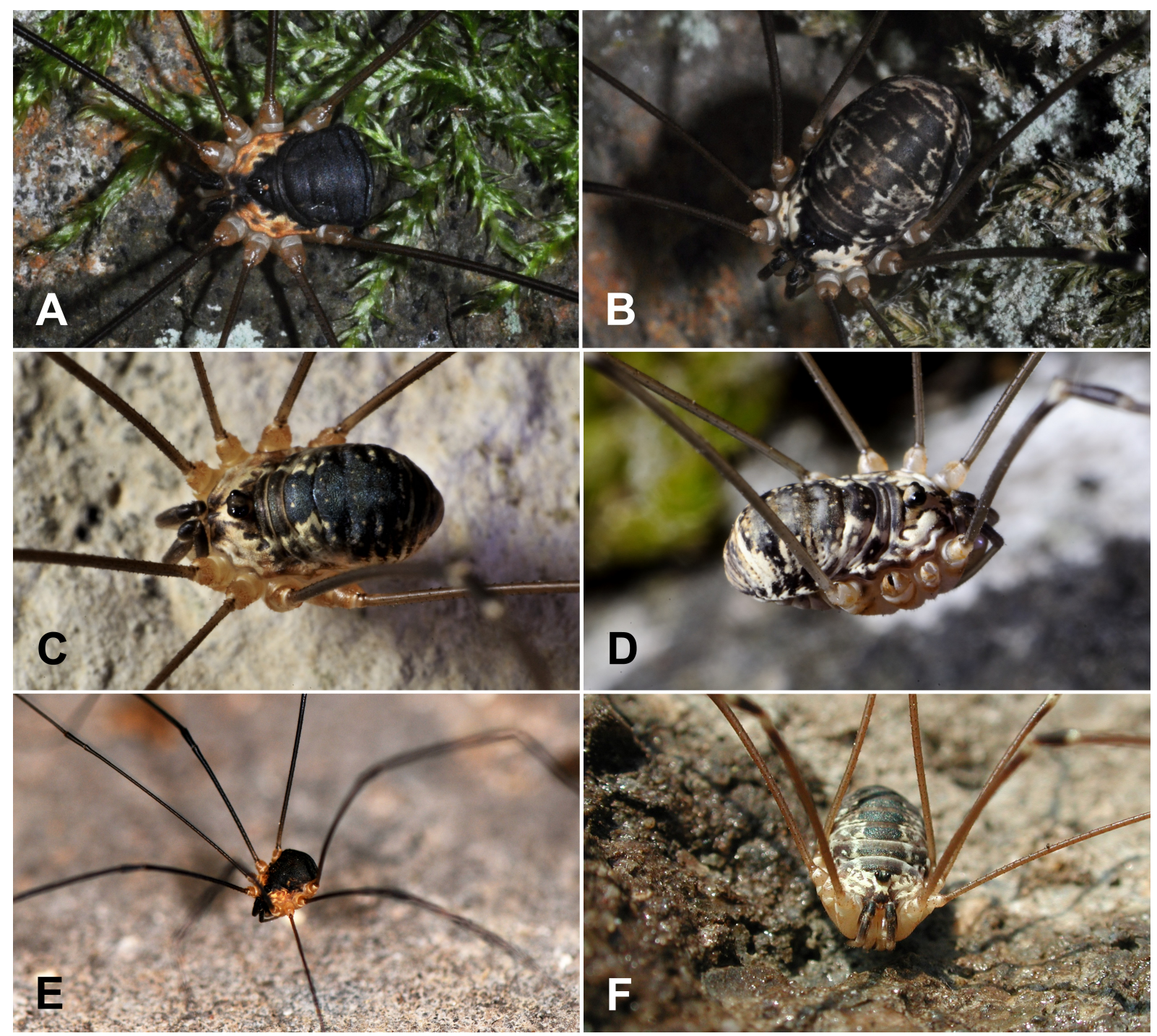

Fig. 1. Habit of Leiobunum rupestre species group. A-B. Leiobunum rupestre Herbst, 1799, Slovenia,

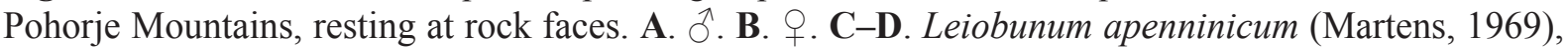
Italy, Monesi di Triora, at night. C. §. D. ․ . E-F. Leiobunum gracile Thorell, 1876, Denmark. E. đ. F. + . Photographs: A-D by A.L.Schönhofer; E-F by S. Toft, all taken in the field. 
Body (Figs 1A-B, 3A-B). In both sexes dorsum smooth, minute granulation not even to be distinguished with magnitude 250 (compare Šilhavý 1981: fig. 4), few scattered pointed granules present; eye mound in both sexes without spines or tubercles.

Dorsal pattern. Male and female (Figs 1A-B, 3A-B): contrasting black and white (see Diagnosis).

Pedipalps. Male (Fig. 4A-B): Fe with irregular rows of marked triangular spines ventrally; dorsally nearly unarmed, ventral spines more slender than in L. gracile; Pt slightly armed with pointed denticles laterally; Ti markedly convex in basal part and concave at ventro-distal end, therefore forming a well-marked S-bend, field of fine dark coloured granules all over the ventral side, well to be seen; Ta continuously and slightly bent to ventral. Female (Fig. 4G-H): similar to male, less spines on Fe and Pt, few spines on Ti proximally and no ventral granulation, Ta strait, slightly bent distally.

Genital morphology (Fig. 5A-C). Truncus penis stout, in ventral/dorsal view from basal opening to insertion of glans slightly and continuously tapering; distal wings covering less than half of truncus. Wings consist of two independent parts: a ventral shell-like plate, sharply cut off horizontally at upper third of wing structure, from its upper margin continuously extending to lateral side of truncus, thus partly embracing the lateral wings which extend from dorsal side of truncus via lateral side to ventral side. Their lower two thirds are covered by the ventral plate. Surface of the upper margin of the lateral wings and membranes adjacent to the truncus is invaginated forming a long double-walled internal sack. At the very distal end of truncus a small membranous oval sack with a distal opening is attached ventrally.

From lateral view truncus slightly curved (concave on ventral side), slightly tapering towards glans. Wings massively enlarged on ventral side. Glans stout, in lateral view tapering towards stylus.

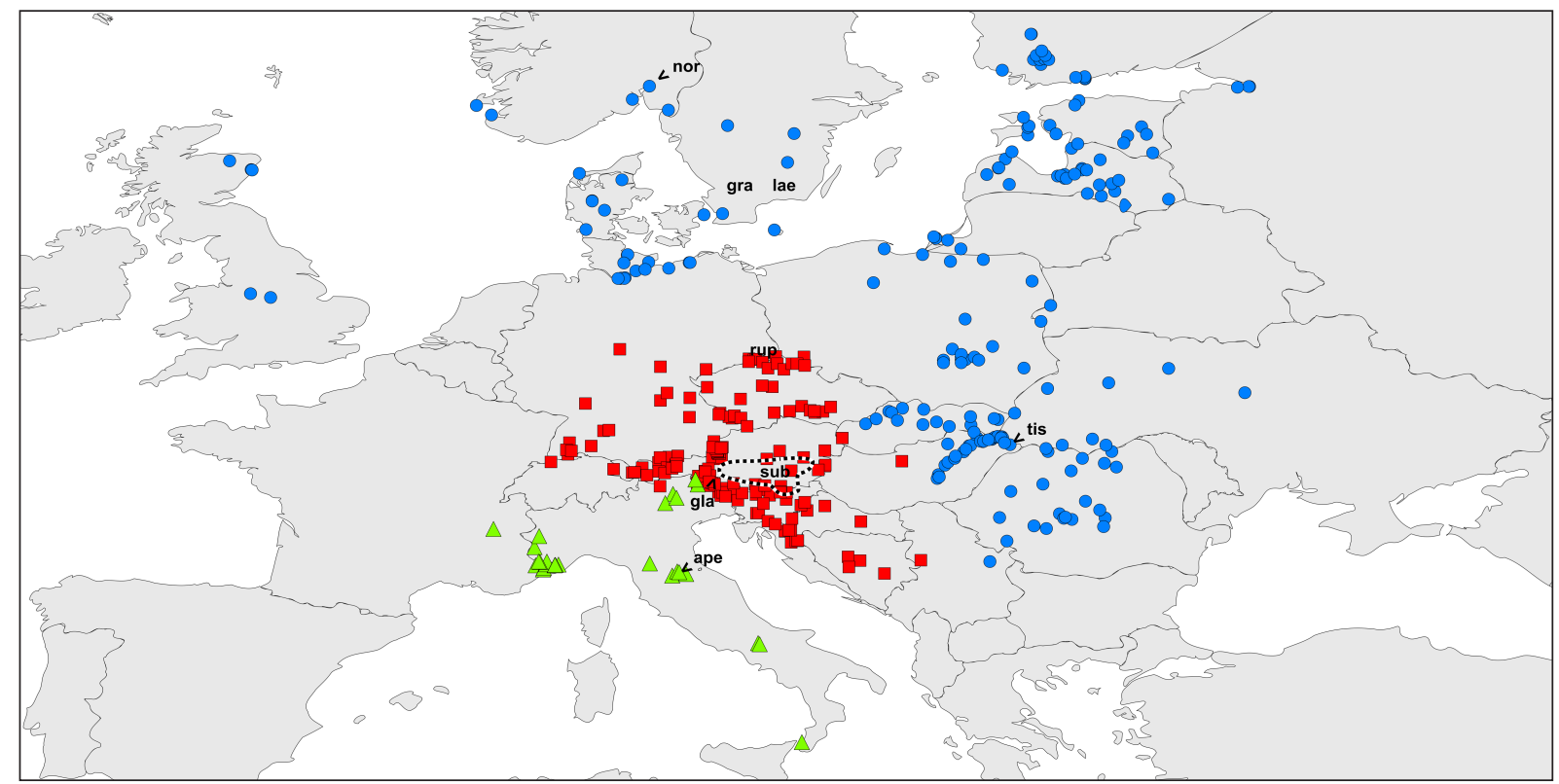

Fig. 2. Distribution of the species of the Leiobunum rupestre species group. Red squares $=$ L. rupestre Herbst, 1799; blue circles = L. gracile Thorell, 1876; green triangles = L. apenninicum $($ Martens, 1969); stippled line circumscribes area of $L$. subalpinum Komposch, 1998. Type localities are indicated by abbreviated taxon names $($ ape $=$ apenninicum $;$ gla $=$ glabrum $;$ gra $=$ gracile $;$ lae $=$ laeve $;$, or $=$ norvegicum; rup = rupestre; sub subalpinum; tis = tisciae) . Arrows indicate a specified locality, if unprecisely given, the general area is indicated (rupestre $=$ Saxony; gracile, laeve $=$ Scania). 


\section{Distribution (Fig. 2)}

Main area are the eastern Alps from the eastern part of Switzerland, all over Austria, the German and Slovenian alpine parts and extending to the north-western Balkan Peninsula. Records extend southwards to Serbia (CJM6363, CIK1336, CIK1337), Croatia (Babić 1916; Novak 2004b) and Bosnia-Hercegovina (Martens 1978; Novak 2005). To the Northeast, the area extends into the Czech Republic: many localities in Bohemia and Moravia, mainly in the northern and southern mountains marking the borders to Austria, Germany and Poland (Šilhavý 1981).

North of the Alps this main Alpine/Balkan area extends in isolated patches towards the northern border of low mountain ranges in Germany (Black Forest, Schwäbische Alb, Frankenalb, Bavarian Forest and Bohemian Forest; all Martens 1978), Fichtelgebirge (Staudt 2016), Thüringer Wald (CJM 5392), Erzgebirge (Büttner 1930), Lausitzer Gebirge (Hiebsch 1972) and northerly up to the Saxonian Elbsandsteingebirge (CJM 4752, 4753). "Sachsen", i.e., Saxony, is the type locality of rupestre, and the type material of Herbst (1799) likely originated from present South Saxony.

For Poland, Stareqga (1976) indicated a number of "rupestre" records in the southern mountains, the Karkonosze (in German "Riesengebirge") close to the Czech border. From the opposite Czech side, in the same mountain stock, the Krkonoše, Šilhavý (1981) pinpointed records for (true) rupestre, which he compared to "glabra" from his country. As these close-to-border Polish localities are situated in mountainous areas, too, they probably belong to rupestre as well. Besides, the Polish 'tisciae' (i.e., gracile, below) records are all situated in lower stretches of central and eastern parts of the country (Staręga 1976, 2004), far from any (possible) mountainous rupestre record.

A
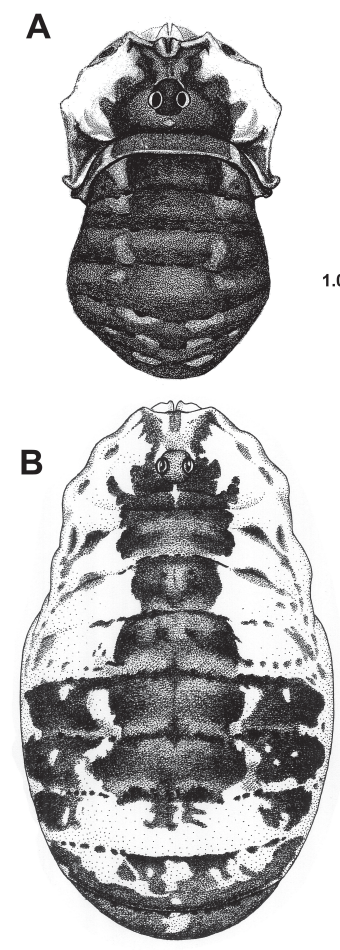

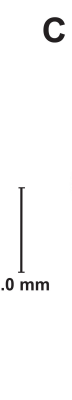

C
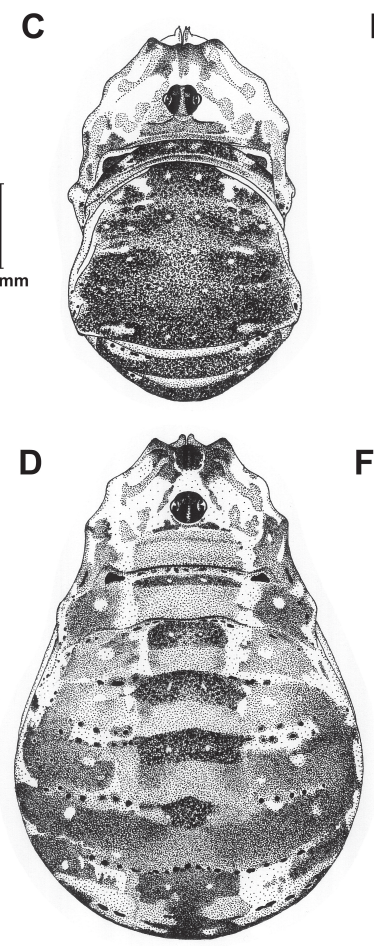

E

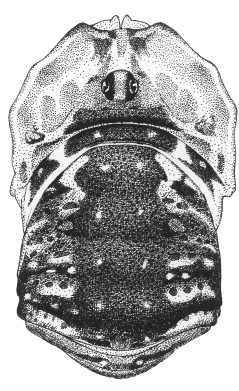

$\mathbf{F}$

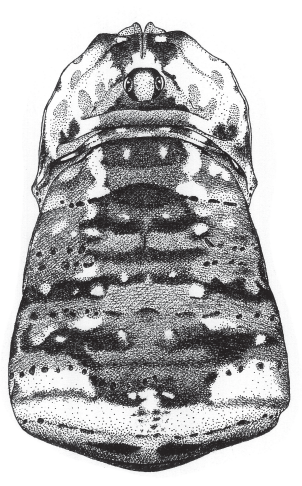

Fig. 3. Body of Leiobunum C.L. Koch, 1839, dorsal view. A-B. Leiobunum rupestre Herbst, 1799, Germany, Mt. Arber, CJM136. A. O̊. B. ̊. - C-D. Leiobunum gracile Thorell, 1876, Denmark. C. ô, $2 \mathrm{~km}$ N of Skærbæk, CJM3530. D. ㅇ, Asp, CJM3531. - E-F. Leiobunum apenninicum (Martens, 1969), France, Alpes-Maritimes. E. O̊, CJM1508. F. ㅇ, CJM2747. Drawings by K. Rehbinder. 
The L. rupestre area as depicted in Martens (1978: fig. 787) needs to be reduced, substracting the distribution area of. $L$. 'tisciae'(i.e., gracile, below), stretching from the Carpathians in a broad northerly area to the Baltic coast up to South Finland and in the West to Denmark and northern Germany (Fig. 2). However, the remaining distribution area of $L$. rupestre slightly changed with respect to the Balkan area, then largely unknown, and new records in central Germany were added.

\section{Ecology}

This is a forest species with a high demand of air moisture. Therefore, it is confined to moist places close to streams and creeks, on tree trunks, under rotten wood and on moist rock faces. It hardly occurs in open areas, in agricultural land, urban gardens or on house walls in villages and towns, if not situated in moist forests (Martens 1978), or at higher altitudes. Martens (1978) indicated height records from $260 \mathrm{~m}$ to $2160 \mathrm{~m}$ a.s.l. in the Austrian Alps, but likely included localities for the closely related L. subalpinum. Komposch \& Gruber (2004) set the Austrian uppermost rupestre limit at $1680 \mathrm{~m}$ a.s.l. and for subalpinum at $2100 \mathrm{~m}$ a.s.1.

In all cases populations of rupestre are confined to mountainous areas of different altitudes. Only in the Saxonian Elbsandsteingebirge does rupestre live at the bottom of deeply recessed valleys which are permanently moist and where sun radiation is largely excluded from the narrow valleys by the steep rock faces.

Leiobunum subalpinum Komposch, 1998

Fig. 2

Leibunum subalpinum Komposch, 1998: 20.

Leiobunum rupestre Gruber, 1966: 46 (partim).

Nelima religiosa Roewer, 1910: 912 (in part: series from Tirol, Groß-Glockner).

Nelima religiosa Thaler, 1966: 79.

Leiobunum sp. - Komposch 1997: 83.

Leibunum subalpinum - Komposch 2009b: 487.

\section{Taxonomic history}

Rather uncomplicated. Because of its extreme similarity to L. rupestre, including genital morphology, this species went unidentified in many former high-altitude reports on $L$. rupestre until its formal description in 1998. Leiobunum rupestre and L. subalpinum occur in sympatry and local syntopy, but coxal markings allow easy field identification, so no further misindications were recorded.

\section{Diagnosis}

A medium-sized Leiobunum species very similar to L. rupestre, except for black coxal markings in both sexes and white markings on Ceph including a white area in front of the tuber oculorum in males. Coxa IV without granules. For further details refer to Komposch (1998).

\section{Description}

Body. See Diagnosis.

DORSAL PATTERN. Extremely similar to L. rupestre.

PedipaLPs. Very similar to L. rupestre except for a medio-basal swelling on Ta in males.

Genital Morphology. Very similar to L. rupestre. The wing-free basal part of truncus shorter than in L. rupestre. 


\section{Distribution (Fig. 2)}

Restricted to the eastern Austrian Alps, mainly on the southern macroslope in the federal states of Salzburg, Steiermark and Kärnten (Komposch 1998; Komposch \& Gruber 2004; Komposch 2009b) extending into adjacent Slovenia (Novak et al. 2006). Type locality is Gößnitztal in the National Park Hohe Tauern in Kärnten.

\section{Ecology}

This a mountainous species of the eastern Alps. Its distributional range extends from about $1500 \mathrm{~m}$ to $2100 \mathrm{~m}$ a.s.l. with rare outliers down to $430 \mathrm{~m}$ in moist and cool ravines and up to $2200 \mathrm{~m}$. Vertical rockfaces mostly of siliceous origin are preferred (Komposch 2009a, b; Komposch \& Gruber 1999). There is a zone of sympatric and sometimes even syntopic occurrence together with $L$. rupestre between $500 \mathrm{~m}$ and $1400 \mathrm{~m}$. Strongholds of L. rupestre in that area extend from $500 \mathrm{~m}$ to $1000 \mathrm{~m}$ with rare occurrences below (down to $200 \mathrm{~m}$ ) and above (up to $1400 \mathrm{~m}$ ) (Komposch 1998).

\section{Leiobunum gracile Thorell, 1876}

Figs 2, 3C-D, 4C-D, K-J, 5D-F

Partly refers to the record within the distribution of L. gracile according to Fig. 2.

Phalangium bicolor Fabricius, 1793: 429.

Liobunum gracile Thorell, 1876: 496 (type series SMNH, examined).

Liobunum laeve Thorell, 1876: 497 (type series SMNH, examined). syn. nov.

Liobunum norvegicum Strand, 1900: 7. syn. nov.

Nelima melanogranulata Morin, 1931 (nomen nudum), 1934 (valid description) syn. to rupestre fide Staręga 1978: 208.

Leiobunum tisciae Avram, 1968: 115 (neither declaration of type specimens nor depository for specimens, material of the original description dedicated by Avram to J.M., now in CJM3526, examined). syn. nov.

Phalangium bicolor - Kulczyński 1876: 61. Remark: see L. rupestre.

Liobunum gracile - Tullgren 1906b: 216 (syn. with L. rupestre).

Liobunum laeve - Tullgren 1906b: 216-217 (syn. with L. rupestre).

Liobunum norvegicum - Tullgren 1906b: 217 (syn. L. rupestre).

Leiobunum tisciae - Martens 1978: 408-412 (partim). — Staręga 2004: 80-81. — Stol 2010b: 35. — Tomasson et al. 2014: 153.

Liobunum rupestre - Tullgren 1906a: 211; 1906b: 216. — Roewer 1910: 203-204.

Leiobunum rupestre - Roewer 1923: 890 (partim). — Heinäjoki 1944: 22-23. — Staręga 1978: 100-103. (partim). - Staręga 1979: 177-178. — Lengyel \& Murányi 2006: 121. — Enghoff 1988: 68-6 9. — Chevrizov 1979: 14. - Spungis 2008: 21.

Nelima gracilis - Roewer 1910: 239, 250 (redescription). — Roewer 1923: 916.

Nelima laevis - Roewer 1910: 239, 251 (redescription). — Roewer 1923: 916.

Nelima norvegica - Roewer 1910: 251 (redescription). — Roewer 1923: 916-917. — Staręga 1976: 100.

Nelima norwegica - Roewer 1910: 239. — Staręga 1976: 100 (sic, lapsus calami).

Liobunum norwegicum - Müller 1920: 72 (lapsus calami).

Strandibunus obliquus - Bartoš 1939: 309.

Nelima glabra - Kolosváry 1965: 111-113. - Kolosváry 1966a: 123. — Kolosváry \& Homonnay 1967: 77-79.

Nelima nigripalpis - Kolosváry 1963: 192. — Kolosváry 1966a, b: 123.

Leiobunum glabrum - Šilhavý 1981: 204-207. 


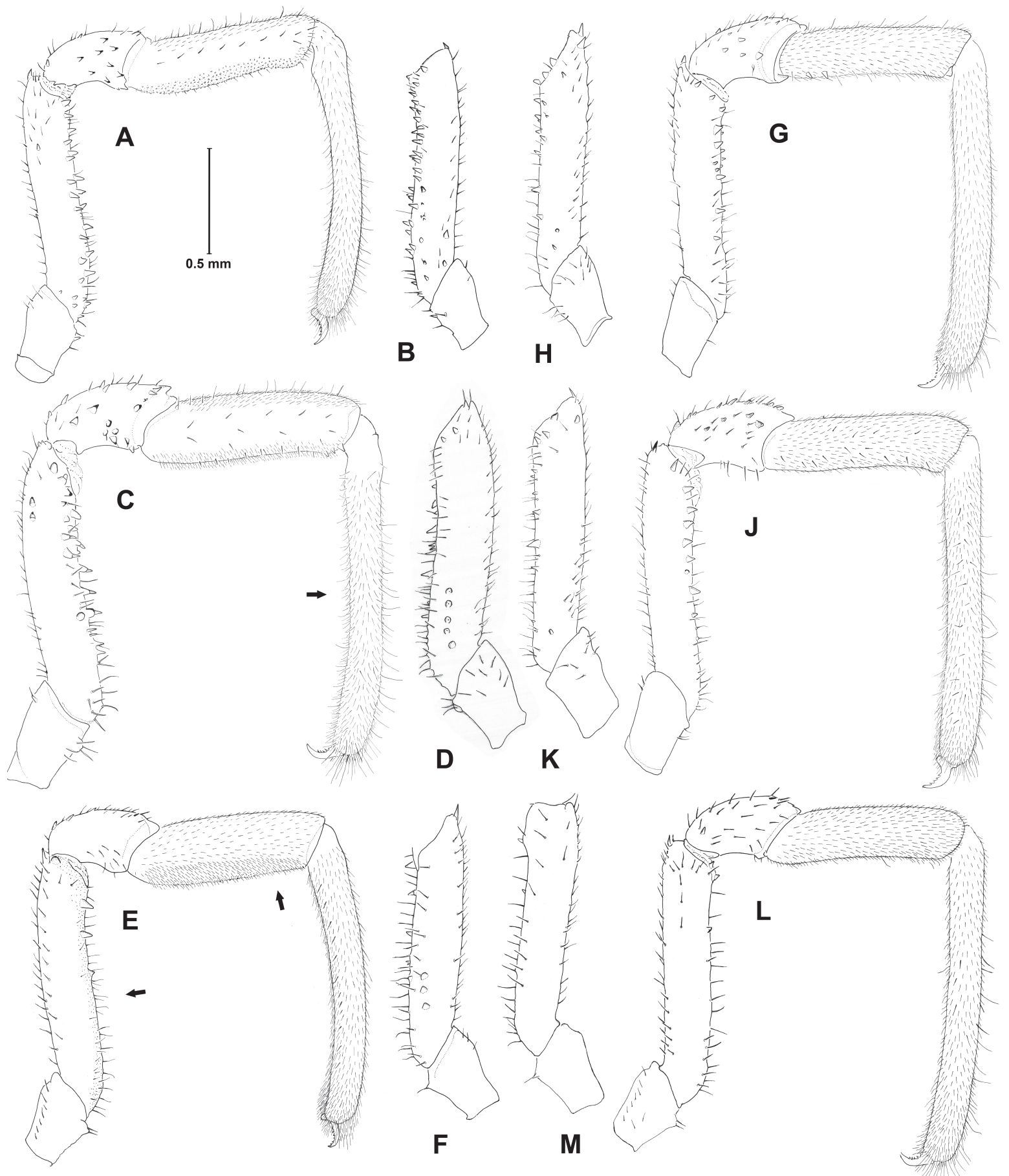

Fig. 4. Pedipalps of the Leiobunum rupestre group, whole pedipalps in lateral view, single femora in medial

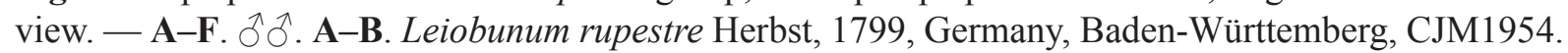
A. Pedipalpus lateral. B. Femur medial. C-D. L. gracile Thorell, 1876, Denmark, Asp, CJM3531. C. Pedipalpus lateral. D. Femur medial. - E-F. Leiobunum apenninicum (Martens, 1969), France, AlpesMaritimes, CJM2747. E. Pedipalpus lateral. F. Femur medial. - G-M. 9 ㅇ. G-H. Leiobunum rupestre Herbst, 1799, Germany, Mt. Arber, CJM136. G. Pedipalpus lateral. H. Femur medial. J-K. L. gracile Thorell, 1876, Denmark, Asp, CJM3531. J. Pedipalpus lateral. K. Femur medial. L-M. L. apenninicum (Martens, 1969), France, Alpes-Maritimes, CJM2747. L. Pedipalpus lateral. M. Femur medial. Arrows indicate characters mentioned in the descriptions. 


\section{Taxonomic history}

A rather complex situation developed because old species names with type localities in various areas in Scandinavia or in (present) eastern locations were never checked in detail. This is partly due to the fact that names were based on juvenile specimens and partly to the unavailability of former authors to access specimens of northern (Baltic) and southern (Alpine) origin for direct comparison. Consequently, northern populations, originally described as Liobunum gracile Thorell, 1876 and Liobunum laeve Thorell, 1876, were permanently affiliated to L. rupestre, starting with Tullgren (1906a, b), followed by Heinäjoki (1944), Staręga (1976) and Martens (1978). The situation became even worse when Avram (1968) described L. tisciae Avram, 1968 from the Tisza valley in Hungary. By external morphology, this species is similar to L. rupestre, which Avram did not take into account. Martens (1978) accepted this novelty but at that time lacked suitable fresh material to identify populations from northern Germany and Denmark as conspecific. Instead, he erroneously treated one species under two names, namely North German and Scandinavian populations under L. 'rupestre' and those from the Carpathians and single individuals from the British Isles under L. tiscae, besides occurrences of $L$. 'rupestre' in the Carpathian Arc as well (Martens 1978). Śilhavý (1981) was the first to recognize two very similar Leiobunum species in (former) Czechoslovakia: L. rupestre in the West (now Czech Republic) and L. 'glabrum' in the East (now Slovakia).

Thorell (1876) based his species L. gracile Thorell, 1876 and L. laeve Thorell, 1876 on juvenile specimens from South Sweden, although he mentioned only a single male. His original material (kept at the Museum of Natural History Stockholm) definitely concerns the types and was examined. It was found, that it indeed only contains juveniles, as already Tullgren (1906b) assumed they represented juveniles of L. rupestre. Likewise, Tullgren (1906b) assumed L. norvegicum Strand, 1900 to be identical with $L$. rupestre, but refrained from making a final decision, not having seen the type material. Describing L. norvegicum, Strand (1900) depicted a female of the L. rupestre complex (from Kristiania [now Oslo]; leg. Sept. 1899) and later Martens (1978) agreed with Tullgren's view, including L. norvegicum in the synonymy of a broad species $L$. rupestre.

Considering the allopatric distribution of $L$. rupestre and $L$. 'tisciae' we now can firmly state that all Leiobunum 'rupestre', based on material from Scandinavia, belong to L. 'tisciae'. But as L. 'tisciae' is a recently proposed name, older names are to be preferred. Albeit $L$. gracile and L. laeve are oldest, their description is based on subadults (Tullgren 1906b). Yet, both have been described from Sweden, Province of Scania, from where Tullgren (1906b) confirmed an adult specimen. Therefore, it seems a reasonable decision to re-establish the oldest available name, Leiobunum gracile Thorell, 1876, and place L. laeve Thorell, 1876, L. norvegicum Strand, 1910 and L. tisciae Avram, 1968 in its synonymy. L. gracile has page and even line priority over L. laeve.

\section{Diagnosis}

A medium-sized Leiobunum species with blackish upper side, except for broad white markings of Ceph disto-laterally in male (Fig. 3C), broad blackish irregular markings on abd area I-V of the body, in female with mottled white markings laterally from Ceph to posterior areae, white lateral marking on abd area $\mathrm{V}$ (Fig. 3D). In both sexes two paramedian small white spots on abd areae I-V, more conspicuous in male (most similar to L. apenninicum). Contrasting yellowish underside including coxae of all appendages. Wings of truncus penis slender, slightly tapering proximally.

\section{Description}

Body (Fig. 3C-D). In both sexes dorsal granulation consists of flat, pointed granules, regularly spaced, well visible at $250 \times$ (compare Šilhavý 1981: fig. 2). 
Dorsal pattern (Fig. 3C-D). See Diagnosis. Tu oc in both sexes smooth, without spines, in rare cases one spine present.

Pedipalps. Male (Fig. 4C-D): Fe with irregular rows of large triangular spines ventrally often with single hair on top; dorsally few on distal part, ventral spines broader and more massive than in L. rupestre, where they are more slender and without hair on top. Pt with scattered denticles la and do; Ti slightly concave ventro-distally, forming a flat S-bend, denticles and hairs on ventral side of palpal tibia light-coloured, hard to be seen; Ta mostly straight, bent only in distal third. Female (Fig. 4J-K): in all members similar to male, but armament less conspicuous, Ti more slender, Ta strait.

Genital morphology (Fig. 5D-F). Penis similar to that of L. apenninicum. Truncus stout, from ventral/ dorsal view from basal opening to insertion of glans slightly and continuously tapering to the internal sac of the wings; lateral wings (ventral view) markedly enlarged, smoothly rounded thus nearly eggshaped (irrespective the lateral membranes running down the truncus). At its very distal end the wing structure close to the glans insertion opens to a small opening, extending into two long nearly parallelsided double-walled sacks to the lower end of the wings. A lateral somewhat invaginated discharged membrane in the distal half of the wings unites the dorso-lateral and the latero-ventral part of the wings

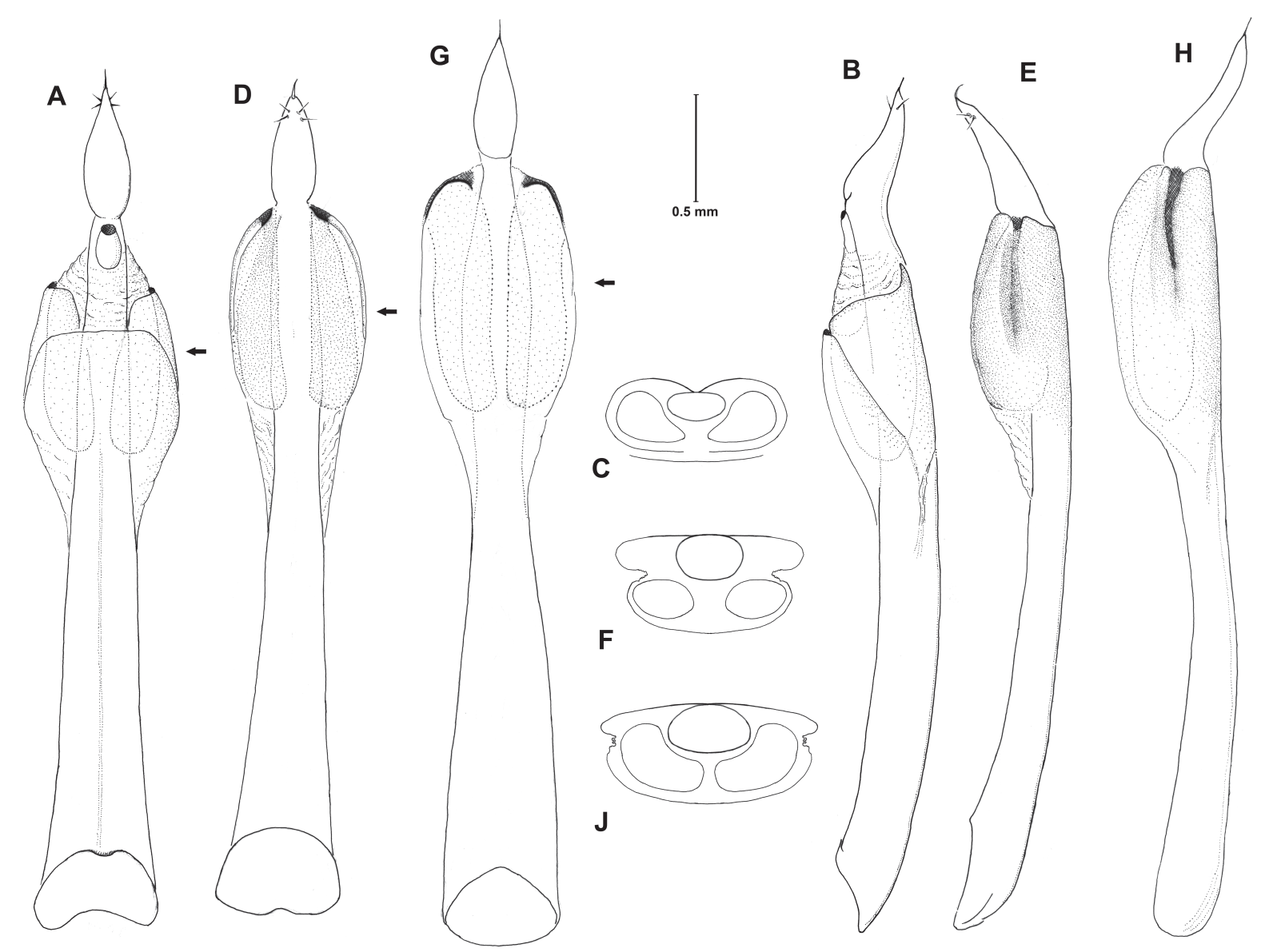

Fig. 5. Leiobunum, male genitalia. A-C. L. rupestre Herbst, 1799, Germany, Baden-Württemberg, CJM1954. A. Ventral view. B. Lateral view. C. Cross-section. - D-F. L. gracile Thorell, 1876, Denmark, $2 \mathrm{~km} \mathrm{~N}$ of Skærbæk, CJM3530. D. Ventral view. E. Lateral view. F. Cross-section. G-J. L. apenninicum (Martens, 1969), France, Alpes-Maritimes, CJM1508. G. Ventral view. H. Lateral view. J. Cross-section. Arrows indicate the area of the respective cross-sections. 
(lateral view) allowing for a possible inflation of the wing structure when the sacs are filled with secretion. From lateral view truncus slightly curved (concave on ventral side), slightly tapering towards basis of stylus. Wings enlarged on ventral side, slightly rounded convexly. Glans broad at truncus insertion, in lateral view continuously tapering towards stylus.

\section{Distribution (Fig. 2)}

From Slovakia (Šilhavý 1981, glabra), northern Hungary including the Tisza valley (type locality of L. tisciae Avram; various records documented by Kolosváry 1963, 1965, 1966a, b, 1969 as nigripalpis and glabra, and Kolosváry \& Homonnay 1967), no additional records in Komposch (2004) for Hungary. Carpathian Arc with many localities documented in collections, but few published papers available, not very far eastward and not in the southern lowlands (Murányi \& Lengyel 2006; Weiss 1996; Cirdeî 1960). In the Southwest the area extends into Serbia (Bor Dubasnica, Mala tisnica, CJM 6363). There are scattered records for the western part of Ukraine, mainly as an extension of the Carpathian area (Bartoš 1939; Cîrdei 1960; Staręga 1978; Morin 1931, 1934; L. Koch 1870). The many records in Poland pertain to the eastern two thirds of the country, extending to the Baltic Sea (Stareqga 1978, 2004, rupestre; for true Polish rupestre see above) and including former Westpreußen. Occurrences in Russia are reported from former Ostpreußen (Le Roi 1914) and from St. Petersburg (CJM 3032), extending to Northeast Poland (Staręga 1976, 2004). Estonia: records along the Baltic Sea Coast (Tomasson et al. 2014). Latvia: partly detailed locality maps (Tumšs 1963; Spungis 2008). Finland: only in the southern part, with detailed map based on monitoring records (Heinäjoki 1944), presence confirmed by Uddström et al. (2013). Germany: records along the Baltic Sea Coast and its hinterland (up to Hamburg), dating back to Kraepelin (1896), Le Roi (1914) and Rabeler (1929), but apparently presently very rare, last record in Schleswig-Holstein, Lübeck in 2007 (CJM 6111; see Martens 1978). Denmark: early records by Hansen (1884), more recent records from all over the country remained largely unchanged between about 1960 (Meinertz 1964) and 1987 (Enghoff 1988), with slight distributional differences, formerly missing from Funen and rare in South Jutland and Himmerland, but very common and abundant there in 1987 (Enghoff 1988), including Funen, South Jutland and Himmerland. Since then, it has vanished, has not been recorded for many years, but it was rediscovered recently and is presently extremely rare. In 2008, four individuals were present on four out of 64 sites (Enghoff et al. 2014). Sweden: except for the early records of Thorell (1876) in Västergötland, Östergötland, Skåne and Småland, there is a single new one from Uppsala in 2009 (examined, H. Enghoff leg.). Norway: Stavanger (SMF) and Oslo (= Kristiania; Strand 1900, norvegicum). Great Britain: Derbyshire (Martens 1978), unrecorded until 2008 when it was found around Aberdeen and Dunbennan, Huntly (Davidson 2009, CJM 6358-6361), in Scotland apparently spreading and in Great Britain presently known from seven counties (British Arachnological Society 2016).

The present distribution of $L$. gracile and that in the recent past obviously represent two different ecological-defined origins. One belongs from lowland to montane and riverine forests, the other one comprises secondary urban habitats to which the species was (most likely) transferred by human activity. Such "anthropogenic" populations may suddenly increase, occupy a large area and sometimes collapse again, for reasons little understood. Others are spot-like with little influence on local faunas. At least for a period of roughly 120 years such dynamics can tentatively be reconstructed (see Discussion).

\section{Ecology}

A euryoecious species. In Slovakia, including the Carpathian Arc, recorded from sheltered places in oldgrowth forests on tree trunks and on rock faces (Šilhavý 1981). It is common in the inundation zone of rivers like the Tisza, e.g., frequently reported from tree hollows of Populus (Avram 1968, tisciae) and Salix trunks (Avram 1968; Csizmazia et al. 1966, nigripalpis; Kolosváry 1963, 1965, 1966a, b). This also holds true for East Poland where gracile lives in forested habitats (Neple, Bug River, AXLS 958). Weiss (1996) indicated its occurrence from Romanian Transylvania forests of the hilly and montane belt. 
In all other areas, which we believe to be secondary, L. gracile is confined to strongly modified and human-influenced habitats. There it competes with other species preferring house walls like Opilio saxatilis C.L. Koch, 1839, O. parietinus (Degeer, 1778) and recently with O. canestrinii Thorell, 1876. In central Europe the latter presently is by far the dominant species in human habitats and may have partly caused the noticeable decline of $O$. saxatilis, O. parietinus and L. gracile (see Discussion).

Leiobunum apenninicum (Martens, 1969)

Figs $1 \mathrm{C}-\mathrm{D}, 2$, 3E-F, 4E-F, M-L, 5G-J

Nelima apenninica Martens, 1969: 409 (type series SMF, examined).

Leiobunum rupestre - Trossarelli 1943: 54. — Gozo 1908: 135.

Nelima apenninica - Martens 1978: 424, figs 803-804, 809. - Chemini 1980: 79 (description of female). — Komposch 2009: 457.

\section{Taxonomic history}

Though only recently described, the status of this large species was accepted by subsequent authors (Chemini 1980; Komposch 2009). However, similarity of genital morphology with L. 'tisciae' (now L. gracile, Martens 1978) later led Martens to the assumption that the scattered distribution of apenninica might represent disjunct area parts of L. gracile. This remained unpublished due to the emerging complex taxonomic situation in L. gracile/L. rupestre. Yet, many details separate both species as is further confirmed by molecular genetic analysis (J. Martens, unpublished data).

The generic affiliation of apenninica is difficult to establish. Certainly, it does not belong to the European bulk of small-bodied Nelima species like N. sylvatica Simon, 1879, N. gothica Lohmander, 1945 and $N$. sempronii Szalay, 1951, but is a large and long-legged species similar to L. gracile, less to L. rupestre. Due to the lack of coxal denticles in the type material and according to the present definition of sclerosomatid genera it was originally placed in Nelima. However, based on only a single external character, this is an artificial affiliation, that we find especially compromised in the species-pair gracile and apenninica. Leiobunum gracile shows a strong variation of number and placement of coxal denticles down to zero (CJM6357, female) and their frequent appearance in Nelima apenninica (AXLS1739 two to seven on coxa IV, in both sexes) underlines the false generic placement of apenninica. Consequently, in accordance with similar genital morphology and external characters we prefer to place apenninica in Leiobunum.

\section{Diagnosis}

A medium-sized Leiobunum species with blackish upper side, except for broad white markings of Ceph disto-laterally in male (Figs 1C, 3E), broad blackish irregular markings on abd areae I-V of the body. In female with mottled white markings laterally from Ceph to posterior areae, white lateral marking on abd area $\mathrm{V}$ and a white cross stripe all over areae VI (Figs 1D, 3F). In both sexes a series of para-median small white spots on the abd areae I-V, more conspicuous in male (a character similar to L. gracile). Contrasting yellowish under side including coxae of all appendages. Wings of truncus penis robust, slightly tapering proximally.

\section{Description}

Body (Figs 1C-D, 3E-F). In both sexes dorsal granulation consisting of flat, pointed granules, regularly spaced, well to be seen with 250× (comparable to L. gracile, see Šilhavý 1981: fig. 2); eye mound in both sexes with 1-3 small spines on each side, rarely absent.

Dorsal pattern (Figs 1C-D, 3E-F). See Diagnosis. 
Pedipalps. Male (Fig. 4E-F): Fe with few massive spines, normally restricted to third ventro-distal part, only single spines on dorso-distal side or absent; Pt unarmed except for few small spines dorsally; Ti slighty inflated, rather short thus appearing pretty massive, brush-like hair field on ventral side, a peculiar character of its own; no spines clearly visible, likely for being of the same light colour as the embedding hair field; Ta continuously bent ventrally over its whole length. Female (Fig. 4M-L): Similar to male. Fe nearly smooth, spines even less than in male, tibia less inflated and slightly concave ventrally, no hair field; tarsus straight, distally inconspicuously bent ventrally, more slender and slightly longer than in male.

Genital morphology (Fig. 5G-J). Penis similar to L. gracile. Truncus stout and parallel-sided in the basal half from where slightly and continuously tapering to the lateral lowest parts of the wings, from there slightly enlarged to middle of the wings, then tapering to basis of glans. Lateral wings (ventral view) markedly enlarged, nearly parallel-sided over nearly their total length, pretty sharply merging to distal part of truncus. At the disto-lateral margin of the wings (close to the truncus/glans joint) wings open to a narrow slit leading to two ventro-lateral pockets. A lateral membrane in the distal half of the wings unites the dorso-lateral und the ventro-lateral part of the wings which allows for a possible inflation of the wing structure when the pockets are filled with secretion. From lateral view truncus slightly curved (concave on ventral side), slightly tapering towards middle part, then enlarging again. Wings massively enlarged on ventral side, slightly rounded convexly. Glans slender, in lateral view tapering towards stylus.

\section{Distribution (Fig. 2)}

It was long considered a rare and local species (Martens 1969; Komposch \& Gruber 2004; Komposch 2009; Chemini 1980) and only a few specimens were available for the original description from the Apennines (Martens 1969). Even fewer became known from the apparently isolated area at the Italian border to Austria (Chemini 1980) and in Austria itself (Martens 1978; Komposch 2009) and the Southwest Alps (Martens 1978). Presently, the area seems to be subdivided into three major parts, viz., French and Italian southwestern Alps, southern Austrian (eastern Tyrol) and Italian Alps (South Tyrol), and scattered records in the Apennines chain. Type locality is Pratovecchio in the Apennines. Yet, there was little additional locality information since its original description until the species was recently rediscovered in the Southwest French Alps in high frequency, namely in the Mercantour National Park and the Vallée des Merveilles (CJM; ALS leg., JM leg). Disregarding its specific habitats and general low sampling activity for long-legged species in the Northwest Alps, the species might have been neglected in large parts of its distributional area. Prior to its description, L. apenninicum has likely been confused with L. rupestre, as is obvious from Trossarelli's (1943) records for the southwest Alps. The isolated record from Calabria (Gozo 1908, L. rupestre; included in Fig. 2) requires confirmation.

\section{Ecology}

This is a forest species. During the day males rest on tree trunks and rock faces; females, though not exclusively, prefer to hide on the ground in leaf litter and thus are not easy to locate. Consequently, only males have long been known, because they are easier to spot and collect. The species is locally pretty common wherever the daytime microhabitats of females are found. Otherwise, it is readily encountered at night, and this technique revealed large populations in the Mercantour National Park in the French Alps.

\section{Discussion}

Systematics of the four central European species Leiobunum rupestre, L. subalpinum, L. gracile and L. apenninicum highlights general problems related to European sclerosomatid taxonomy. Firstly, in this case old, but available names, have been largely neglected and were not compared to species known from the area. Subsequent species proposals, i.e., Leiobunum norvegicum or Leiobunum tisciae ignored this 
point and caused considerable taxonomic confusion. Old names, though available, were not considered in detail and simply put aside. On the other hand, Leiobunum subalpinum, a species very similar to L. rupestre but not rare at all in its limited alpine area, escaped taxonomic recognition for about 200 years. Furthermore, the artificial division of Leiobunum into Leiobunum s. str. and Nelima proposed by Roewer (1910) and maintained for a century seems to be inappropriate in the case presented here. The Roewerian separation is based solely on the presence (Leiobunum) or absence (Nelima) of coxal denticles, but does not place "Leiobunum" and "Nelima" species into reasonable morphological and much less preferably monophyletic units, which is substantiated by results of modern molecular genetics (Hedin et al. 2012). In our example, "Nelima" apenninica normally does not generally bear such denticles, but its male genital morphology is astonishingly similar to that of $L$. gracile to an extent that one might even suppose conspecifity. "Leiobunum" gracile is reported to have highly variable numbers of coxal denticles (Avram 1968) and partly none, while our material also revealed several individuals of "Nelima" apenninica to have few denticles, too. Molecular genetic analyses indeed demonstrate close relations (J. Martens, unpublished data), confirming the specific differences. The taxon apenninica belongs to Nelima only by Roewer's genus definition, genetically and genital-morphologically it is affiliated to a group of central European Leiobunum. However, "Leiobunum", presently a holarctically distributed genus, is heterogeneous as well and refers to a number of morphologically and genetically distinct lineages, which are far from being disentangled (Hedin et al. 2012). From our material it is also apparent that an increase of the number of denticles, as well as their presence on more than one coxa is linked to an increased body size of the individual, at least in apenninica and gracile. Such a variable character is certainly inappropriate to serve for differentiation of higher level taxa within a highly heterogeneous phylogenetic group. A molecular-based re-organization, not only of the European Leiobunum/Nelima complex, is in urgent need.

The distributional analysis revealed that Leiobunum gracile and L. apenninicum, though closely related, show a very different distributional pattern. Leiobunum apenninicum is a conservative forest species, apparently confined to a few scattered areas and presently with little perceivable tendencies to enlarge its distribution.

The closely related $L$. gracile, however, massively enlarged its area in close affinity to man-made habitats around the Baltic Sea coast. In this area of expansion its populations considerably fluctuate in numbers and it can constrict its area down to local disappearance. Parts of the Carpathian Arc and the adjacent mountains in Southwest Poland and Slovakia and low-altitude riverine forests in Hungary may represent the original area of the species, though this is difficult to substantiate. "Natural" populations may be indicated by hilly and montane forests, also riverine localities where high population densities are obvious (Avram 1968; Csizmazia \& Kolosváry 1966; Kolosváry 1963, 1965, 1966a, b, 1969; Kolosváry \& Homonnay 1967).

However, it remains arbitrary to solidify area limits of an original and an expansive population based on ecological comparison of historical records. It is thus only hypothesized that starting from the Carpathians the Baltic coast area and its hinterland have been colonized, possibly by help of human-mediated transport. All Baltic authors (Rabeler 1929; Kraepelin 1896; Le Roi 1914; Heinäjoki 1944; Tumšs 1963; Meinertz 1964; Enghoff 1988; Enghoff et al. 2014; Staręga 1978, 2004) emphasize the close proximity to human settlements in their area, such as in gardens, specifically on house walls and similar environments, while forest habitats played a minor role in all ecological characterisations. In the Baltic area, this presumed invasion of new areas was successful, but to the West, the North Sea coast was not reached, at least not in a continuous belt, with the westernmost localities around Hamburg (Kraepelin 1896). Isolated outposts are known from the British Isles (Martens 1978) including Scotland (British Arachnological Society 2016), where the population seems to prosper. 
A reasonable proof of newly gained territories is the fact that in the newly colonized areas population densities are high in "disturbed" habitats, remain stable for a certain period and after years or even decades collapse or finally completely disappear. This holds true for the population in Denmark, stable at least from the mid 1960s (Meinertz 1964) to 1987, when Enghoff (1988) undertook another monitoring and found an even more extended territory inhabited. Presently, L. gracile has largely disappeared from Denmark (Enghoff et al. 2014). Likewise in northern Germany only a few isolated records were reported between 2000 and 2009 (Staudt 2016), while the species appeared common at the beginning of the last century (Kraepelin 1896; Rabeler 1929; Le Roi 1914). Other occurrences remained spot-like from the very beginning and apparently disappeared soon after the first discovery in Great Britain (Martens 1978, tisciae) or gained new area spots far away in Scotland and other parts of the U.K. (British Arachnological Society 2016).

Reasons for such extreme population fluctuations are unclear and have not been surveyed in detail. Population decline was obvious for long prior to the invasion of Opilio canestrinii to central Europe, which started about 1970 (Martens 1978, as ravennae, first German records in Stuttgart 1974 CJM1619; Mainz 1975 CJM1525; Berlin 1976 CJM1553). For the year 1987 Enghoff (1988) stated that L. gracile and $O$. canestrinii lived side by side in high population densities in Denmark. Only gracile disappeared, canestrinii remained to the present and is common everywhere (Toft 2004, pers. comm.). However, it must be taken into account that long-lasting effects of high population density of $O$. canestrinii may have caused the decline of L. gracile. The same is assumed for Opilio parietinus in central Europe.

The temporal invasion of the Baltic dates back for at least 120 years, probably considerably longer. Kraepelin (1896) mentioned gracile as not being rare for the Hamburg area whereas Heinäjoki (1944) stated that gracile invaded Finland and gained northward territory only in the 1920s. Monitoring of the Finnish arachnid fauna was pretty detailed at that time and earlier occurrences would have been certainly noticed as indicated by Heinäjoki (1944), who documented the extension to about $61.6^{\circ} \mathrm{N}$ up to Hämeenkyrö, until today the northernmost known record (Uddström et al. 2013). For Denmark records date back to the $19^{\text {th }}$ century, when Hansen (1884) mentioned the species.

\section{Acknowledgements}

We are much indebted to A. Ausobsky, A. Babalean, H. Enghoff, M.B. Davidson, S. Huber, P. Jäger, I. Karaman, Ch. Komposch, M. Lemke, H. Pieper, W. Staręga and S. Toft who provided material and information for the study of this difficult group. T. and S. Novak, R. Ozimec, J. Wolff, A. Grabolle, S. Huber, M. Isaia and M. Paschetta further helped with field collections. H. Enghoff translated Danish text and provided data at an early stage of manuscript work. M. Grasshoff and P. Jäger allowed access of the arachnid collection of the Senckenberg Natural History Museum Frankfurt. K.A. Johanson and G. Lindberg at the Natural History Museum Stockholm gave advice and access to Thorell's types. K. Rehbinder created the beautiful drawings of dorsal body patterns. Wagner Foundation and Feldbausch Foundation at Fachbereich Biologie of Mainz University granted annual financial support for ecological and systematic studies on harvestmen in Europe and Asia to J.M. A.L.S. collected European Leiobunum in the Alps with the help of traveling funds from DAAD (2006) and EDIT/ATBI+M (2008). Finally, we greatly acknowledge the helpful remarks and hints of two anonymous reviewers. We heartily thank all friends, colleagues and institutions.

\section{References}

Ausobsky A. 1987. Verbreitung und Ökologie der Weberknechte (Opiliones, Arachnida) des Bundeslandes Salzburg. Mitteilungen aus dem Haus der Natur 10: 40-52. 
Avram Ş. 1968. Contribution à l'étude des Opilionides de la zone inondable de la Tisa entre les kilomètres fluviaux 698-744. Avec la description d'une nouvelle espèce: Leiobunum tisciae. Tiscia, Szeged 4: 111125.

Avram Ş. \& Dumitrescu D.O. 1969. Contribuţii la cunoaşterea răspîndirii geografice şi a ecologiei opilionidelor cavernicole, endogee şi epigee, din România. [Contributions à la connaissance de la répartition géographique et de l'écologie des Opilions cavernicoles, endogés et épigés, de Roumanie.] Lucrările Institutului de Speologie «Emil Racoviţă» 8: 99-145. [In Romanian].

Babić K. 1916. Opilionidi hrvatskog zemaljskog zoološkog muzeja u Zagrebu [Die Opilioniden des kroatischen zoologischen Landesmuseums zu Zagreb]. Glasnik hrvatskoga prirodoslovnoga društva 28: 169-179. [in Croatian] Available from http://biodiversitylibrary.org/page/11087817 [accessed 23 Jun. 2016]

Bartoš E. 1939. Die Weberknechte (Opiliones) des östlichen Carpaticums. Folia Zoologica et Hydrobiologica 9 (2): 308-310.

Breuss W. 1995. Zum Vorkommen von Arthropoden in einigen Höhlen Vorarlbergs (Österreich) (Arachnida, Hexapoda, Crustacea). Berichte des naturwissenschaftlich-medizinischen Vereins in Innsbruck 82: 227240.

British Arachnological Society. 2016. Spider and Harvestman Recording Scheme website - Leiobunum tisciae. Available online from http://srs.britishspiders.org.uk/portal/p/Summary/s/Leiobunum+tisciae [accessed 5 Jan. 2016]

Büttner K. 1930. Beitrag zur Kenntnis der der Kankerfauna Südwestsachsens. Jahrbuch des Vereins für Naturkunde Zwickau 1928-1930: 22-25.

Cantoni E. 1882. Escursione in Calabria (1877). Chernetidi ed Opilionidi. Bollettino della Società Entomologica Italiana 14: 191-203.

Caporiacco L. di 1922. Saggio sulla fauna aracnologia della Carnia e regioni limitrofe. Memorie della Società Entomologica Italiana, Genova 1: 60-111.

Chemini C. 1980. Alcuni reperti di Opilioni dalle Alpi Italiane (Arachnida, Opiliones). Studi Trentini di Scienze Naturali, Serie B, Biologica 56: 71-79.

Chevrizov B.P. 1979. A brief key of the harvest-spiders (Opiliones) in the European territory of the USSR. The Fauna and Ecology of Arachnida. Proceedings of the Zoological Institute Leningrad 85: 4-27. [in Russian]

Cîrdei F. 1960. Contribution à l'étude des opilionides du nord-est de la R.P.R. et du bassin supérieur du Pruth. Analele Ştiinţifice ale Universităţii „,Al. I. Cuza“ din Iaşi (Serie 2) 6: 77-95. [in Russian]

Csizmazia G., Homonnay S., Kolosváry G. \& Nógrádi S. 1966. Neuere Daten zur Fauna des Tiszatales. Tiscia 2: 83-88.

Daday J. 1896. Ordo Opiliones. A Magyar Birodalom Állatvilága [Fauna Regni Hungariae] 3. Arthropoda, Magyar Természettudományi Társulat, Budapest. [in Hungarian and Latin]

Dalla-Torre K.W. 1882. Beiträge zur Arthropodenfauna Tirols. Berichte des naturwissenschaftlichmedizinischen Vereins in Innsbruck 12: 32-73.

Davidson M.B. 2009. Arachnids Dunbennan Cemetery, Aberdeenshire. Part 2: A leiobunid harvestman new to Scotland and the British Isles? Newsletter of the British arachnological Society 114: 11.

Dobat K. 1963. Die Fauna der Gutenberger Höhlen. Jahrbücher für Karst- und Höhlenkunde 4: 287301. 
Enghoff H. 1988. Operation Opilio 1987 - an investigation of harvestmen on walls, fences and similar habitats in Denmark (Opiliones). Entomologiske Meddelelser 56: 65-72.

Enghoff H., Pedersen J. \& Toft S. 2014. Dansk mejere - en fauna i vækst. Entomologiske Meddelelser 82: 1-12. [in Danish]

Gozo A. 1908. Gli Aracnidi di caverne italiane. Bullettino della Società Entomologica Italiana 38: 109139.

Gruber J. 1966. Neues zur österreichischen Opilionidenfauna (Arachnida). Zeitschrift der Arbeitsgemeinschaft österreichischer Entomologen 18 (2/3): 43-47.

Gruber J. 2000. Neue Weberknechtfunde aus Niederösterreich und angrenzenden Gebieten (Arachnida: Opiliones). Zeitschrift der Arbeitsgemeinschaft österreichischer Entomologen 52: 15-22.

Hadži J. 1931. Opilioni Triglavskoga masiva [Die Opilionen des Triglavmassivs]. Prirodoslovne Razprave (Muzejsko Drustvo za Slovenijo) Ljubljana 1: 107-154. [in Slovenian, German abstract]

Hammelbacher K. 1986. Untersuchung über die Verbreitung von Weberknechten (Opiliones) in unterschiedlichen Lebensräumen (1. Zwischenbericht 1986) FO 03/6/11 - 696/85. Zoologisches Institut III, Ökologische Außenstation Steigerwald der Universität Würzburg, Würzburg.

Hansen H.J. 1884. Arthrogastra Danica: en monographisk fremstilling af de i Danmark levende Meiere og Mosskorpioner med bidrag til sidstnaevnte underordens systematic. Naturhistorisk Tidsskrift (3) 14: 491-554. [in Danish]

Hedin M., Tsurusaki N., Macías-Ordóñez R. \& Shultz J.W. 2012. Molecular systematics of sclerosomatid harvestmen (Opiliones, Phalangioidea, Sclerosomatidae): geography is better than taxonomy in predicting phylogeny. Molecular Phylogenetics and Evolution 62: 224-236. http://dx.doi.org/10.1016/j. ympev.2011.09.017

Heinäjoki M. 1944. Die Opilionidenfauna Finnlands. Acta zoologica Fennica 42: 1-26.

Hiebsch H. 1972. Beiträge zur Spinnen- und Weberknechtfauna des Neißetales bei Ostritz. Abhandlungen und Berichte des Naturkundemuseums Görlitz 47: 1-32.

Herbst J.F.W. 1799. Natursystem der ungeflügelten Insekten 3. Fortsetzung der Naturgeschichte der Insectengattung Opilio. Vol 3. Lange, Berlin.

Hippa H. 1975. Faunistic and ecological notes on the Opilionid fauna (Opilionida) of south-west Häme, Finland. Lounais-Hämeen Luonto 55: 1-4.

Jurinac A.E. 1886. Faunistični pabirci po okolini krapinskoj. Glasnik Hrvatskoga Naravoslovnoga družtva 1: 145-153. [in Croatian] Available from http://biodiversitylibrary.org/page/11273665 [accessed 23 Jun. 2016]

Kirchner W. \& Salzer R. 1967. Ein Beitrag zur Kenntnis der Opilioniden der Casentinesischen Forsten. Bollettino della Societa Entomologica Italiana 97 (9-10): 157-162.

Koch C.L. 1848. Die Arachniden. Sechzehnter Band. J.L. Lotzbeck, Nürnberg. Available from http:// biodiversitylibrary.org/page/16576103 [accessed 23 Jun. 2016]

Koch L. 1861. Bemerkungen zur Arachniden-Familie der Opilioniden. Correspondenz-Blatt des zoologisch-mineralogischen Vereines in Regensburg 15 (9): 131-144. Available from http:// biodiversitylibrary.org/page/11882527 [accessed 23 Jun. 2016]

Koch L. 1869. Beitrag zur Kenntniss der Arachnidenfauna Tirols. Zeitschrift des Ferdinandeums für Tirol und Vorarlberg, Innsbruck, series 3 (14): 149-206. 
Koch L. 1870. Beiträge zur Kenntniss der Arachnidenfauna Galiziens. Jahrbuch der kaiserlichköniglichen Gelehrten Gesellschaft in Krakau 41: 1-56.

Koch C. 1871. Beiträge zur Kenntniss der Opilioniden des Mittel-Rhein-Gebietes. Bericht über die Tätigkeit des Offenbacher Vereins für Naturkunde 12: 52-91. Available from http://biodiversitylibrary. org/page/35404205 [accessed 23 Jun. 2016]

Koch L. 1877. Verzeichnis der bei Nürnberg bis jetzt beobachteten Arachniden (mit Ausschluß der Ixodiden und Acariden) und Beschreibungen von neuen, hier vorkommenden Arten. Abhandlungen der naturhistorischen Gesellschaft zu Nürnberg 6: 113-198. Available from http://biodiversitylibrary.org/ page/28860075 [accessed 23 Jun. 2016]

Kofler A. 1984. Faunistik der Weberknechte Osttirols (Österreich) (Arachnida: Opiliones). Berichte des naturwissenschaftlich-medizinischen Vereins in Innsbruck 71: 63-82.

Kofler A. \& Mildner P. 1986. Beitrag zur Weberknechtfauna Kärntens. Carinthia II, 176./96: 113-120.

Kolosváry G. 1929. Magyarország Kaszáspókjai. Die Weberknechte Ungarns (Opilionida). Studium Verlag, Budapest.

Kolosváry G. 1963. Das Leben der Tisza XXI. Opilioniden des Gebietes der Inundationsräume der Tisza. Acta Biologica, Szeged NS 9 (1-4): 191-193.

Kolosváry G. 1964. Énumération des opilionides reconnus dans la vallée de la rivière Tisza (Parthissus). Bulletin mensuel de la Société Linnéenne de Lyon 33: 372.

Kolosváry G. 1965. Opilioniden aus dem nördlichen Tiszatal. Tiscia, Szeged 1: 111-113.

Kolosváry G. 1966a. Über Ökologie der Weberknechte der Inundationsräume der Theiss. Tiscia, Szeged 2: $121-125$.

Kolosváry G. 1966b. Nouvelle énumération des Opilionidés dans la vallée de la rivière Tisza. II. Bulletin mensuel de la Société Linnéenne de Lyon 35: 247-248.

Kolosváry G. 1969. Opilioniden der oberen und mittleren Tisza-Gegend. Tiscia, Szeged 5: 79-81.

Kolosváry G. \& Homonnay S. 1967. Weitere zoologische Beobachtungen im nördlichen Tiszatal. Tiscia, Szeged 3: 75-81.

Komposch C. 1997. Die Weberknechtfauna (Opiliones) des Nationalparks Hohe Tauern. Faunistischökologische Untersuchungen von der Montan- bis zur Nivalstufe unter besonderer Berücksichtigung des Gößnitztales. Wissenschaftliche Mitteilungen aus dem Nationalpark Hohe Tauern 3: 73-96

Komposch C. 1998. Leiobunum subalpinum n. sp.- ein neuer Weberknecht aus den Ostalpen (Opiliones: Phalangiidae). Wissenschaftliche Mitteilungen aus dem Nationalpark Hohe Tauern 4: 19-40.

Komposch C. 2004. The harvestman fauna of Hungary (Aracnioda, Opiliones). In: Samu F. \& Szinetár C. (eds) European Arachnology. Proceedings of the 20th European Colloquium of Arachnology, Szombathely, 22-26 Jul. 2002: 227-242, Plant Protection Institute, Budapest.

Komposch C. 2008. Auf arachnologischen (Ab)Wegen - Spinnen, Weberknechte und Skorpione am Millstätter See. In: Honsig-Erlenburg W. \& Golob B. (eds) Der Millstätter See. Aus Natur und Geschichte. Verlag des Naturwissenschaftlichen Vereins für Kärnten, Klagenfurt.

Komposch C. 2009. Rote Liste der Weberknechte (Opiliones) Österreichs. In: Zulka K.P. (ed.) Rote Listen gefährdeter Tiere Osterreichs. Checklisten, Gefährdungsanalysen, Handlungsbedarf. Teil 3: Flusskrebse, Zikaden, Köcherfliegen, Skorpione. Weberknechte: 397-483. Grüne Reihe des Lebensministeriums 14/3, Böhlau Verlag, Wien. 
Komposch C. \& Gruber J. 1999. Vertical distribution of harvestmen in the Eastern Alps (Arachnida: Opiliones). Bulletin of the British Arachnological Society 11: 131-135.

Komposch C. \& Gruber J. 2004. Die Weberknechte Österreichs (Arachnida, Opiliones). Denisia NS 12: 485-534.

Kraepelin K. 1896. Phalangiden aus der Umgebung Hamburgs. Mitteilungen aus dem naturhistorischen Museum in Hamburg 13: 219-234. Available from http://biodiversitylibrary.org/page/29521651 [accessed 23 Jun. 2016]

Kulczyński W. 1876. Dodatek do fauny pajęczaków Galicyi [Addition to arachno-fauna of Galicia]. Sprawozdanie Komisyi Fizjograficznej 10: 41-67. [in Polish]

Latreille P.A. 1804. Huitième genre - Dixième genre et particulière des Crustacés et des Insectes. In: Sonnini C.S. (ed.) Histoire naturelle, générale et particulière des Crustacés et des Insectes 7: 314-329. F. Dufart, Paris. Available from http://biodiversitylibrary.org/page/24883291 [accessed 23 Jun. 2016]

Le Roi O. 1914 (for 1913). Zur Kenntnis der Opilioniden-Fauna von Norddeutschland. Schriften der Physikalisch-ökonomischen Gesellschaft zu Königsberg in Preußen 54 (3): 257-272. Available from http://biodiversitylibrary.org/page/48939328 [accessed 11 Jul. 2016]

Lengyel G.D. \& Murányi D. 2006. Data to the Hungarian harvestmen (Opiliones) fauna. Folia Historico Naturalia Musei Matraensis 30: 117-128.

Lessert R. de 1917. Opilions. Catalogue des invertébrés de la Suisse 9: 1-80, Muséum d'Histoire Naturelle de Genève, Genève.

Löser S., Meyer E. \& Thaler K. 1982. Laufkäfer, Kurzflügelkäfer, Asseln, Webespinnen, Weberknechte und Tausendfüßler des Naturschutzgebietes 'Murnauer Moos' und der angrenzenden westlichen Talhänge (Coleoptera: Carabidae, Staphylinidae; Crustacea: Isopoda; Aranei; Opiliones; Diplopoda). Entomofauna Linz Suppl. 1: 369-446.

Marcellino I. 1971. Opilioni dell'Appennino centrale. Lavori della Società Italiana di Biogeografia. N.S. 2: 401-422.

Marcellino I. 1973. Notizie su Opilioni (Arachnida) italiani e dell'Alto Isonzo. Annali del Museo Civico di Storia Naturale di Genova 79: 192-205.

Marcellino I. 1975. Opilioni (Arachnida) delle alpi occidentali. Bollettino del Museo Civico di Storia Naturale di Verona 2: 119-144.

Martens J. 1969. Mittel- und südeuropäische Arten der Gattung Nelima (Arachnida: Opiliones: Leiobunidae). Senckenbergiana biologica 50 (5/6): 395-415.

Martens J. 1978. Spinnentiere, Arachnida - Weberknechte, Opiliones. Die Tierwelt Deutschlands 64, VEB Gustav Fischer, Jena.

Mazzucco K. 1967. Bericht der Beobachtungsstation Weißsee 1966. Zeitschrift der Wiener Entomologischen Gesellschaft 52: 111-135.

Meinertz T. 1964. Eine zootopographische Untersuchung über die dänischen Opilioniden. Videnskabelige Meddelelser Naturhistorisk Forening i København 126: 417-449.

Morin S.M. 1931. Materialy po faune Opiliones (senokostsev) Ukrainy. In: Schmalhausen I. (ed.) Trudy Chetvertogo Vsesoyuznogo S'ezda Zoologov, Anatomov, i Gistologov [Proceedings of the IV. Congress of the Zoologists, Anatomists, and Histologists of the U.S.S.R.] (Kiev-Har'kov, 6-12 May 1930): 59-61. Gosmedizat SSSR, Kiev. [in Ukrainian]

Morin S.M. 1934. Materiali do fauni Opilionid-kosariv Ukraïni. Trudy Zoologo-biologichnogo Institutu, Odesa Universitet 1934: 11-38. [in Ukrainian] 
Müller A. 1920. Zur Kenntnis der Opilionidenfauna des Urwaldes von Bialowies. Abhandlungen der Senckenbergischen Naturforschenden Gesellschaft 37: 71-88.

Müller F. \& Schenkel E. 1895. Verzeichnis der Spinnen von Basel und Umgegend. Verhandlungen der naturforschenden Gesellschaft zu Basel 10: 691-824. Available from http://biodiversitylibrary.org/ page/34087160 [accessed 23 Jun. 2016]

Murányi D. \& Lengyel G.D. 2006. Contribution to the Opiliones fauna of Maramureş county, Romania. Studia Universitatis "Vasile Goldis" Arad 17: 77-83.

Novak T. 2004a. Harvestmen of the Museo Friulano di Storia Naturale in Udine (Arachnida: Opiliones). Part I. Gortania. Atti del Museo Friulano di Storia Naturale 26: 211-241.

Novak T. 2004b. An overview of harvestmen (Arachnida: Opiliones) in Croatia [Pregled faune kosaca (Aachnida: Opiliones) u Hrvatskoj]. Natura Croatica 13 (3): 231-296.

Novak T. 2005. An overview of harvestmen (Arachnida: Opiliones) in Bosnia and Herzegovina. Natura Croatica 14 (4): 301-350.

Novak T. \& Gruber J. 2000. Remarks on published data on harvestmen (Arachnida: Opiliones) from Slovenia. Annales, Series historia naturalis 10 (2/21): 281-308.

Novak T., Delakorda S.L. \& Novak L.S. 2006. A review of harvestmen (Arachnida: Opiliones) in Slovenia. Zootaxa 1325: 267-276.

Rabeler W. 1929. Mecklenburgische Weberknechte (Opiliones). Archiv des Vereins der Freunde der Naturgeschichte in Mecklenburg NF 4: 73-82.

Roewer C.F. 1910. Revision der Opiliones Plagiostethi (= Opiliones Palpatores). I. Teil: Familie der Phalangiidae. (Subfamilien: Gagrellini, Liobunini, Leptobunini.) Abhandlungen aus dem Gebiete der Naturwissenschaften, herausgegeben vom Naturwissenschaftlichen Verein in Hamburg 19 (4): 1-294.

Roewer C.F. 1923. Die Weberknechte der Erde. Systematische Bearbeitung der bisher bekannten Opiliones. G. Fischer Jena.

Roewer C.F. 1957. Über Oligolophinae, Caddoinae, Sclerosomatinae, Leiobuninae, Neopilioninae und Leptobuninae (Phalangiidae, Opiliones Palpatores). (Weitere Weberknechte XX). Senckenbergiana biologica 38 (5/6): 323-358.

Roşca A. 1930. Contribuţiuni la cunoaşterea Arachnoidelor din Bucovina. Buletinul Facultaţii de Ştiinţe din Cernauţi 4 (2): 201-219. [in Romanian]

Schönhofer A.L. 2005. Mittel- und nordeuropäische Weberknechte aus dem Senckenberg-Museum Frankfurt (Arachnida: Opiliones). Arachnologische Mitteilungen 30: 25-31.

Šilhavý V. 1948. Les Opilions de la steppe de Serpentine près de la ville de Mohelno. Mohelno. Archiv Svazu na výzkum a ochranu přirody i krajiny v zemi Moravskoslezské 8: 1-108. [in Czech, French summary]

Šilhavý V. 1956. Sekáči - Opilionidea. Fauna ČSR 7. Akademia Nauk, Praha. [in Czech]

Šilhavý V. 1981. Occurrence of Leiobunum glabrum in Czechoslovakia (Arach., Opilionidea). Věstník československé Společnosti zoologické [Acta societatis zoologicae bohemoslovacae] 45 (3): 204-208.

Simon E. 1879. Les Arachnides de France. Tome 7. Contenant les ordres des Chernetes, Scorpiones et Opiliones. Librairie Encyclopédique de Roret, Paris.

Spungis V. 2008. Fauna, distribution, habitat preference and abundance of harvestmen (Opiliones) in Latvia. Latvijas Entomologs 45: 14-24. 
Staręga W. 1963. Kosarze (Opiliones) okolic Warszawy. Weberknechte (Opiliones) der Umgegend von Warszawa. Fragmenta Faunistica, Warszawa 10 (25): 379-390.

Staręga W. 1976. Opiliones Kosarze (Arachnoidea). Fauna Polski 5: 1-197, Polska Akademia Nauk, Warsaw.

Staręga W. 1978. Katalog der Weberknechte (Opiliones) der Sowjet-Union. Fragmenta Faunistica, Warszawa 23 (10): 197-234.

Staręga W. 1979. Kosarze (Opiliones) Pienin. Fragmenta Faunistica Warszawa 24 (5): 175-183.

Staręga W. 2004. Interessante Weberknechtfunde aus Polen (Arachnida: Opiliones). Arachnologische Mitteilungen 27/28: 78-88.

Staudt A. 2016. Nachweiskarten der Spinnentiere Deutschlands (Arachnida: Araneae, Opiliones, Pseudoscorpiones): Weberknechte, Sclerosomatidae, Leiobunum rupestre. Available online from: http://www. spiderling.de/arages/Verbreitungskarten/species_eng.php?name=Leiobunum rupestre [accessed 3 Jan. 2016]

Stipperger H. 1928. Biologie und Verbreitung der Opilioniden Nord-Tirols. Arbeiten aus dem Zoologischen Institut der Universität Innsbruck 3 (2): 17-79.

Stol I. 2003. Distribution and ecology of harvestmen (Opiliones) in the Nordic countries. Norwegian Journal of Entomology 50 (1): 33-41.

Stol I. 2010a. Vevkjerringfaunaen (Opiliones) på Karmøy i Rogaland. Fauna 62 (3): 60-63.

Stol I. 2010b. Vevkjerring-faunaen (Opiliones) på Østlandet. Insekt-Nytt 35 (2): 31-36.

Strand E. 1900. Zur Kenntnis der Arachniden Norwegens. Det Kongelige Norske Videnskabers Selskabs Skrifter 2: 2-15. Available from http://biodiversitylibrary.org/page/32313917 [accessed 23 Jun. 2016]

Thaler K. 1963. Spinnentiere aus Lunz (Niederösterreich). Berichte des naturwissenschaftlichmedizinischen Vereins in Innsbruck 53: 273-283.

Thaler K. 1966. Zur Arachnidenfauna der mittleren Ostalpen. Senckenbergiana biologica 47: 77-80.

Thorell T. 1876. Sopra alcuni Opilioni (Phalangidea) d'Europa e dell'Asia occidentale, con un quadro dei generi europei di quest'Ordine. Annali del Museo civico di storia naturale di Genova 8: 452-508. Available form http://biodiversitylibrary.org/page/7916212 [accessed 23 Jun. 2016]

Tomasson K., Tammru T. \& Kurina O. 2014. Harvestmen (Arachnida: Opiliones) in Estonia: results of the Estonian Malaise Trap Project. Entomologica Fennica 25: 142-156.

Trossarelli F. 1943. Contributo allo studio degli Opilionidi Italiani. Bollettino della Società Entomologica Italiana 75 (5): 49-54.

Tullgren A. 1906a. Låckespindlar. Phalangidea. Entomologisk Tidskrift 27: 206-213. [in Swedish]

Tullgren A. 1906b. Notiser rörande arter af Arachnidgrupperna Chelonethi och Phalangidea. Entomologisk Tidskrift 27: 214-218. [in Swedish]

Tumšs V. 1963. Über die Weberknechtefauna (Opiliones) der Lettischen SSR. Latvijas Entomologs 7: 53-58. [in Latvian]

Uddström A., Rinne V. \& Pajunen T. 2013. Opiliones new to Finland and an updated checklist. Memoranda Societatis pro Fauna et Flora Fennica 89: 1-3.

Wajgel L. 1874. Pajęczaki galicyjskie (Arachnoidea haliciae). Kołomyja, published by the author.

Weiss I. 1996. Die Weberknechtfauna Siebenbürgens. (Arachnida: Opiliones). Stapfia 45: 259-280. 
Werner F. 1931. Beitrage zur Kenntnis der Tierwelt Ost-Tirols. Veröffentlichungen des Museum Ferdinandeum in Innsbruck 11: 1-12.

Wijnhoven H., Schönhofer A. \& Martens J. 2006. An unidentified harvestman Leiobunum sp. alarmingly invading Europe (Arachnida: Opiliones). Arachnologische Mitteilungen 34: 27-38.

Manuscript received: 2 February 2016

Manuscript accepted: 5 April 2016

Published on: 27 July 2016

Topic editor: Rudy Jocqué

Desk editors: Niko Korenhof \& Kristiaan Hoedemakers

Printed versions of all papers are also deposited in the libraries of the institutes that are members of the EJT consortium: Muséum national d'Histoire naturelle, Paris, France; Botanic Garden Meise, Belgium; Royal Museum for Central Africa, Tervuren, Belgium; Natural History Museum, London, United Kingdom; Royal Belgian Institute of Natural Sciences, Brussels, Belgium; Natural History Museum of Denmark, Copenhagen, Denmark; Naturalis Biodiversity Center, Leiden, the Netherlands. 
Appendix 1 - List of material and distributional data

\section{Remarks}

The list incorporates investigated material and references, which we judged sufficiently reliable. Old or alternative locality names, interpretations and accuracy of coordinate-reconstruction are indicated in parenthesis. Important taxonomic material, such as types, are indicated in bold.

Acronyms of institutions cited in the list

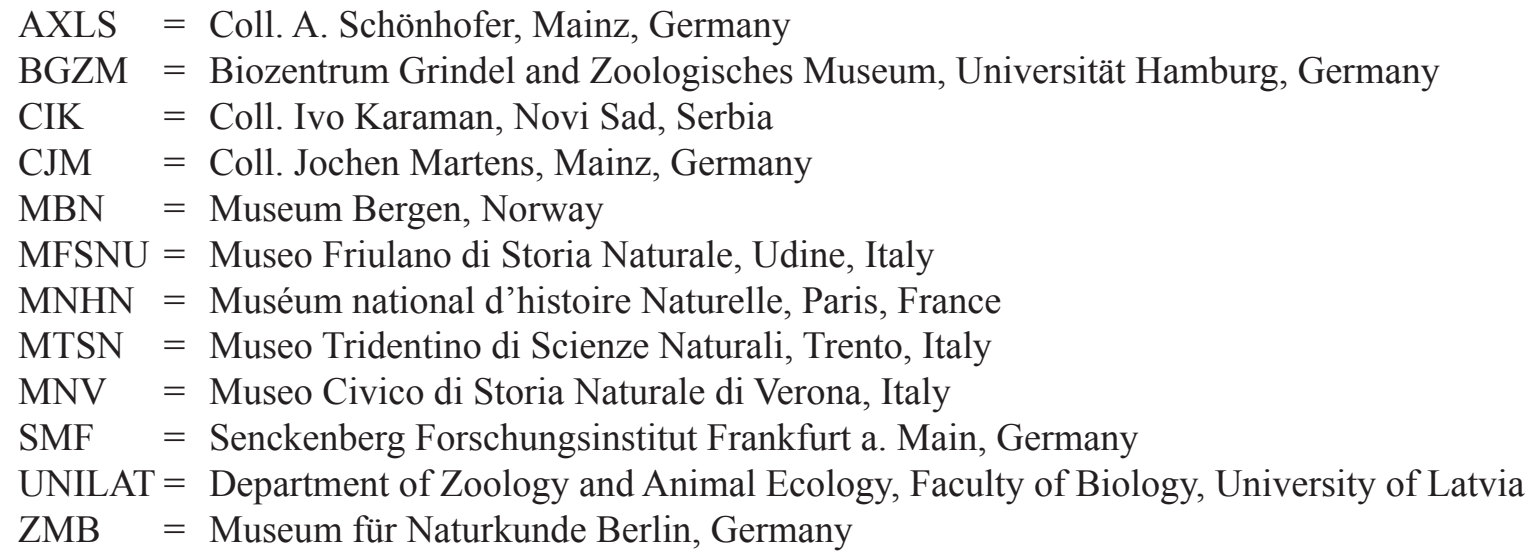

Leiobunum apenninicum (Martens, 1969)

AUSTRIA: Osttirol, Arnbach near Sillian, 1100 m, 46.74 N, $12.39^{\circ}$ E, leg. A. Ausobsky, 15 Jun. 19?? (Martens 1978); Defereggental, banks of river Schwarzach below Mariahilf, $1670 \mathrm{~m}, 46.913^{\circ} \mathrm{N}, 12.31^{\circ} \mathrm{E}$, leg. 31 Aug. and 1 Sep. 2007 (Komposch 2009).

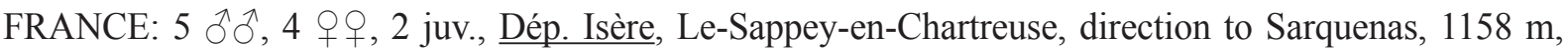
mixed coniferous and Fagus forest, under bark and logs, $45.273^{\circ}$ N, 5.766 E, leg. 31 Aug. 2008 (AXLS30); 3 juv., Dép. Alpes-Maritimes, buffer area of the Mercantour National Park, focal site La Minière de Valaura (9), $1476 \mathrm{~m}$, mixed forest on north facing slope, under stones and logs, $44.069^{\circ} \mathrm{N}$, 7.132 ${ }^{\circ}$ E, leg. 5 Sep. 2008 (MNHN); 4 juv., same locality, below Col de Turini, $1513 \mathrm{~m}$, coniferous forest, under logs and bark, $43.977^{\circ}$ N, 7.386 ${ }^{\circ}$ E, leg. 3 Sep. 2008 (AXLS85); 1 đ̆, Forêt de Peïra Cava,

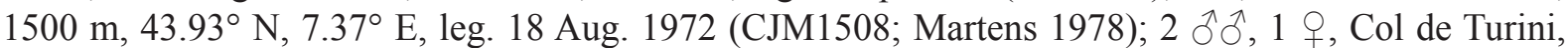
$1500 \mathrm{~m}$, Picea forest, below pass, $43.978^{\circ} \mathrm{N}, 7.390^{\circ} \mathrm{E}$, leg. 19 Sep. 1982 (CJM2747); 28 ふふર, 2 우 ㅇ, 15 juv., Mercantour National Park, focal site Valmasque (7), 1905 m, NW exposed slope, very humid, indicated by predominance of Alnus viridis, at stems of Larix, $44.111^{\circ} \mathrm{N}, 7.473^{\circ} \mathrm{E}$, leg. 6 Sep. 2008 (CJM6295).

ITALY: 6 ô, Prov. Arezzo, Casentino, Bibbiena vicinity, P. di Mandioli (interpreted as Passo di

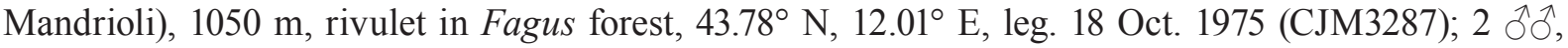

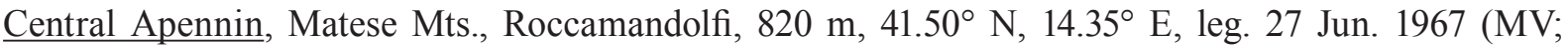
Marcellino 1971; Martens 1978); 1 §o, Sotto Rifugio Campitello, 1250 m, $41.463^{\circ} \mathrm{N}, 14.394^{\circ} \mathrm{E}$, leg. 22 Sep. 1967 (MV; Marcellino 1971; Martens 1978); Emilia Romagna, Prov. Bologna, 1 q, "Corno alle Scale" Park (coordinates inaccurate), 44.14 $\mathrm{N}, 10.83^{\circ} \mathrm{E}$, leg. 2005 (online source Tree of Life,

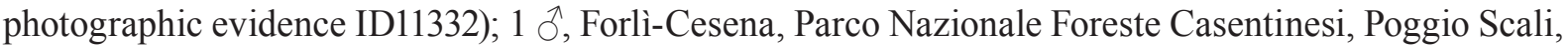
Monte Falterone, 1520 m, 43.845 N, 11.79 E, leg. Sept. 1963 (SMF16433; Martens 1969; cf. Kirchner \& Salzer 1967; holotype of Leiobunum apenninicum (Martens, 1969)); 2 ô, same locality, Campigna, $1050 \mathrm{~m}, 43.87^{\circ} \mathrm{N}, 11.73^{\circ} \mathrm{E}$, leg. Sept. 1963 (SMF16434; Martens 1969, paratypes); 1 , 1 , Pratomagno, E Firenze, Vallombrosa (interpreted as the abbey), $1100 \mathrm{~m}$, Abies forest, $43.732^{\circ} \mathrm{N}$, 
11.558 E, leg. 17 Oct. 1975 (CJM3282); Prov. Imperia, 9 ad., 1 juv., Monesi di Triora, $1300 \mathrm{~m}$, stream valley before village, night catch, $44.081^{\circ} \mathrm{N}, 7.761^{\circ} \mathrm{E}$, leg. 30 Aug. 2014 (AXLS1733); 1 ○े, first stream valley before village, $1400 \mathrm{~m}$, in deep stony gravel and sieved from litter in-between, $44.071^{\circ} \mathrm{N}$,

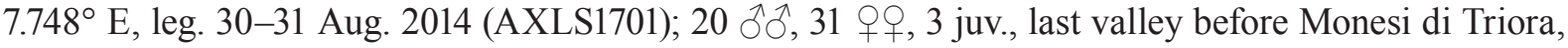
$1287 \mathrm{~m}$, sitting on dry leaf litter (often under fallen twigs) in mixed forest, $44.081^{\circ} \mathrm{N}, 7.767^{\circ} \mathrm{E}$, leg. 9 Sep. 2008 (CJM6308); 1 ${ }^{2}$, Monesi di Triora, 1304 m, deciduous forest (Fagus), under stones, 44.082 ${ }^{\circ}$

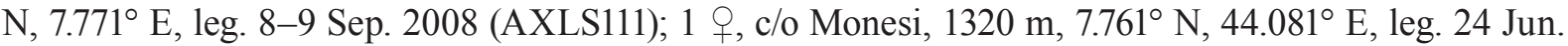
2011 (AXLS1150); 1 §̊, Alpi Cozie, Crissolo, Monviso, 1300 m, $44.67^{\circ} \mathrm{N}, 7.10^{\circ} \mathrm{E}$, leg. July 1967 (MV; Marcellino 1975); 1 ${ }^{\lambda}, \mathrm{N}$ Pinerolo, Giaveno, W Forno (interpreted as Forno), $950 \mathrm{~m}, 45.04^{\circ} \mathrm{N}, 7.24^{\circ}$ E, leg. 9 Oct. 1972 (CJM1576; Martens 1978); 8 ठోळ, 4 우, 4 juv., Alpi Marittimi, National Park Alpi Marittime, focal site Palanfré, $1501 \mathrm{~m}$, old N-exposed Fagus sylvatica forest, sitting on leaf litter, $44.195^{\circ} \mathrm{N}, 7.494^{\circ} \mathrm{E}$, leg. 10 Sep. 2008 (MNHN); 1 juv., focal site Vallone d' Argentera, $1580 \mathrm{~m}$, coniferous

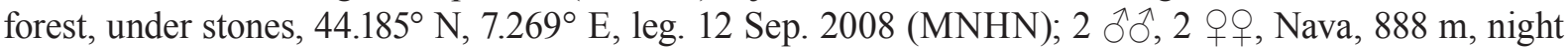
catch alongside deciduous forest and stream, mostly on road, $44.099^{\circ} \mathrm{N}, 7.874^{\circ} \mathrm{E}$, leg. 7 Sep. 2008 (AXLS108); 4 ठึ่, 2 우우, Val de Valasco, Rifugio Valasco, $1800 \mathrm{~m}, \mathrm{~N}$-facing slope with large boulders, Alnus viridis and Myrtillus shrubs, under stones and in crevices, $44.196^{\circ} \mathrm{N}, 7.233^{\circ} \mathrm{E}$, leg. 28 Aug. 2014

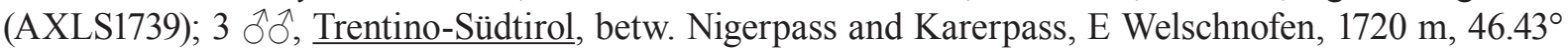

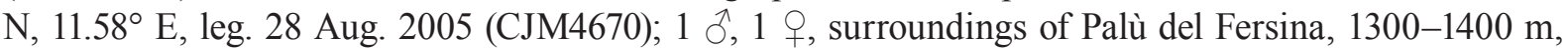
$46.13^{\circ} \mathrm{N}, 11.34^{\circ} \mathrm{E}$, leg. 8 Sep. 1973 (MTSN, Chemini 1980); 1 ô, surroundings of Paneveggio, $1500 \mathrm{~m}$, $46.31^{\circ} \mathrm{N}, 11.70^{\circ} \mathrm{E}$, leg. 28 Aug. 1973 (MTSN, Chemini 1980). Calabria, Valletta della grotta della Melia, $38.23^{\circ} \mathrm{N}, 15.76^{\circ} \mathrm{E}$ (Cantoni 1882; Gozo 1908; orig. det. as L. rupestre and is here affiliated to $L$. apenninicum; requires confirmation).

Leiobunum gracile Thorell, 1876

\section{Remarks}

Leiobunum gracile was mostly considered under the names $L$. rupestre and L. tisciae. These names we used for the original identification of records in the literature. The repetitive information was omitted, while more unusual species taxa names and identifications (glabra, nigripalpe, etc.) are given. If necessary, please refer to the respective publication.

DENMARK: 3 ô $^{\Uparrow}, 2$ q $q, 1$ juv., $2 \mathrm{~km} \mathrm{~N}$ of Skærbæk, coniferous forest, $55.17^{\circ} \mathrm{N}, 8.76^{\circ} \mathrm{E}$, leg. $16-30 \mathrm{Sep}$.

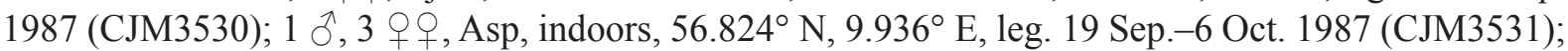

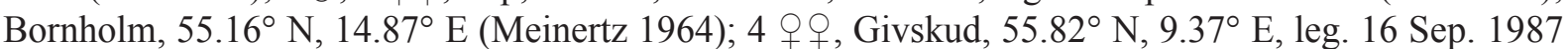

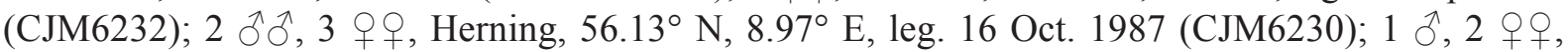

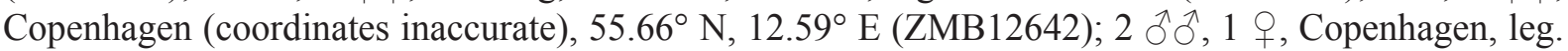

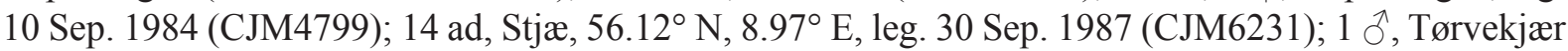
v. Klitmøller, $57.03^{\circ} \mathrm{N}, 8.55^{\circ} \mathrm{E}$, leg. 2 Dec. 2006 (CJM6229).

ESTONIA: All Estonian records refer to Tomasson et al. 2014 based on 3-4 sampling periods of 4-7 months in 2008-2011. 3 ex., Harju, Üksnurme, unmanaged old apple orchard next to cultivated grassland, $59.295^{\circ} \mathrm{N}, 24.628^{\circ} \mathrm{E}$; 15 ex., Hiiu, Kerema, moist alvar grassland with juniper brush, $58.891^{\circ} \mathrm{N}$, $22.948^{\circ} \mathrm{E}$; 116 ex., Jõgeva, Pataste, moist forest dominated by alder, birch, bird cherry, spruce, $58.581^{\circ} \mathrm{N}$, $26.778^{\circ} \mathrm{E} ; 18$ ex., Lääne, Kunila, Moist broad-leaved forest, $58.631^{\circ} \mathrm{N}, 23.811^{\circ} \mathrm{E} ; 1$ ex., Pärnu, Nigula NR, paludified pine forest with Polytrichum, $58.007^{\circ} \mathrm{N}, 24.712^{\circ} \mathrm{E} ; 11$ ex., Pärnu, Tõstamaa, next to brush covered ditch bank surr. by fallow grassland, $58.336^{\circ} \mathrm{N}, 24.006^{\circ} \mathrm{E} ; 56$ ex., Saare, Igaküla, Pine forest with Corylus, $58.601^{\circ}$ N, $23.128^{\circ}$ E; 18 ex., Saare, Orissaare, patch of deciduous managed forest in an urban area, $58.555^{\circ} \mathrm{N}, 23.087^{\circ} \mathrm{E}$; 1 ex., Saare, Viidumäe, edge of a spring fen, $58.294^{\circ} \mathrm{N}$, $23.089^{\circ}$ E; 108 ex., Tallin, $59.44^{\circ} \mathrm{N}, 24.75^{\circ}$ E (Staręga 1978); 108 ex., Tartu, Maiorg, spruce and aspen dominated old forest along a rivulet valley, $58.278^{\circ} \mathrm{N}, 26.334^{\circ} \mathrm{E} ; 136$ ex., Tartu, Sudaste, Oxalis-type 
drained spruce forest, $58.329^{\circ} \mathrm{N}, 26.940^{\circ} \mathrm{E} ; 11$ ex., Valga, Puka, edge of paludified forest, Filipendula type, $58.041^{\circ} \mathrm{N}, 26.207^{\circ} \mathrm{E} ; 48$ ex., Võru, Leoski, edge of dry boreal forest, Vaccinum myrtillus type, $57.709^{\circ} \mathrm{N}, 27.139^{\circ} \mathrm{E}$.

FINLAND: 2 juv., Espoo, 60.21 N, 24.65 E, leg. 17-18 Jul. 1940 (Heinäjoki 1944); Häme, Forssa, $60.82^{\circ} \mathrm{N}, 23.63^{\circ} \mathrm{E}$ (Hippa 1975); Tammela, $60.80^{\circ} \mathrm{N}, 23.77^{\circ} \mathrm{E}$ (Hippa 1975); Ypäjä, $60.80^{\circ} \mathrm{N}, 23.28^{\circ} \mathrm{E}$

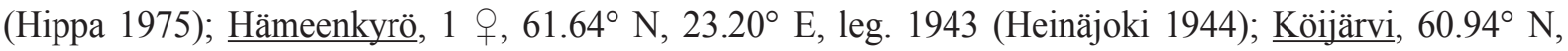

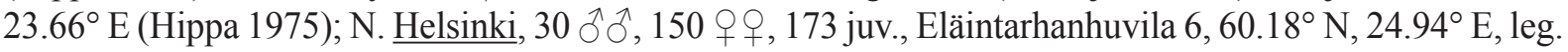
1935-40 (Heinäjoki 1944); 1 juv., Käpylä, indoors at wall, $60.21^{\circ}$ N, $24.95^{\circ}$ E, leg. 3 Aug. 1925 (Heinäjoki 1944); Oulunkylä and Pakinkylä, on path and indoors, $60.23^{\circ} \mathrm{N}, 24.94^{\circ} \mathrm{E}$, leg. late summer 1943 (Heinäjoki 1944); 1 ô, Ullanlinna, indoors at wall, $60.16^{\circ} \mathrm{N}, 24.95^{\circ} \mathrm{E}$, leg. 25 Sep. 1926 (Heinäjoki 1944); Southern Finland, Humppila, $60.93^{\circ} \mathrm{N}, 23.37^{\circ} \mathrm{E}$ (Hippa 1975); Jokioinen, $60.80^{\circ} \mathrm{N}, 23.48^{\circ} \mathrm{E}$ (Hippa 1975); $\underline{\text { St. }}$ Hämeenkyrö, 1 ad., on a path, $61.635^{\circ} \mathrm{N}, 23.193^{\circ} \mathrm{E}$, leg. 20 Sep. 1943 (Heinäjoki 1944); Turku (coordinates inaccurate), 1 ô, 1 \% $, 60.45^{\circ} \mathrm{N}, 22.26^{\circ}$ E, leg. 25 Sep. 1926, 9 May 1927 (Heinäjoki 1944); Western Finland, Somero, $60.63^{\circ} \mathrm{N}, 23.52^{\circ}$ E (Hippa 1975); Urjala, $61.08^{\circ} \mathrm{N}, 23.54^{\circ} \mathrm{E}$ (Hippa 1975).

GERMANY: Hamburg (three localities), large numbers (coordinates inaccurate), $53.56^{\circ} \mathrm{N}, 9.87^{\circ} \mathrm{E}$

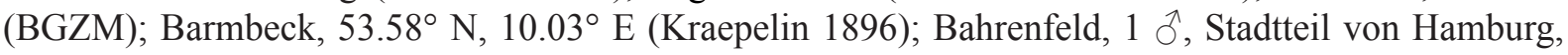

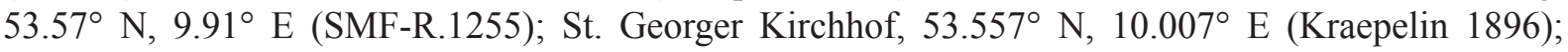
Blankenese, $53.56^{\circ} \mathrm{N}, 9.81^{\circ} \mathrm{E}$ (Kraepelin 1896); Mecklenburg-Vorpommern, 1 ex., Rostock, house garden in nesting box (Rabeler 1929); 4 ex., Rostock, old cemetery at Saarplatz (now abandoned), at houses and walls, $54.085^{\circ} \mathrm{N}, 12.117^{\circ} \mathrm{E}$, leg. 8 Oct. 1927-1929 (Rabeler 1929); 1 ex, Rostock, yard of the Entomology Seminar, 54.088 N $12.134^{\circ}$ E, leg. 7 Oct. 1927-1929 (Rabeler 1929); 1 ex., Rostock, indoors, leg. 7 Nov. 1927-1929 (Rabeler 1929); 3 ex., Rostock, Wallanlagen, in cracks of wall, 54.087

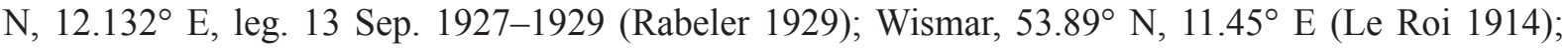

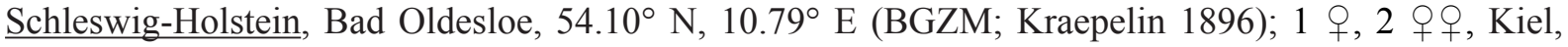
Institute of Zoology, 54.33 N, 10.1 ${ }^{\circ} \mathrm{E}$, leg. 1 Sep. 1964 (CJM949, CJM6172); 1 đo, 1 ㅇ, Lübeck, former School of Navigation, on wall, $53.861^{\circ} \mathrm{N}, 10.689^{\circ} \mathrm{E}$, leg. 9 Oct. 2007 (CJM6111); 1 ${ }^{\top}, 4$ q $q$, Neumünster (72), $20 \mathrm{~m}, 54.07^{\circ} \mathrm{N}, 9.99^{\circ} \mathrm{E}$, leg. $17+27$ Sep. 1964 (CJM6171); Neumünster(?) (coordinates inaccurate), $1 \overbrace{}^{\lambda}, 54.07^{\circ} \mathrm{N}, 9.99^{\circ} \mathrm{E}$, leg. Sep. 1967 (CJM948).

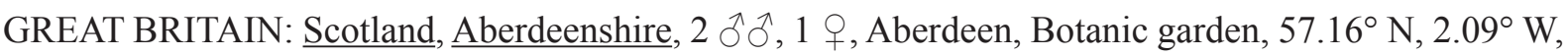

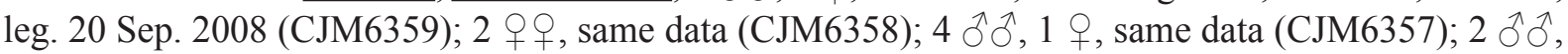
1 q, Aberdeen, Torry, Greyhope House, 57.142 ${ }^{\circ} \mathrm{N}, 2.062^{\circ} \mathrm{W}$, leg. 9 Oct. 2008 (CJM6361); 1 ㄱ, 3 우우, same data, leg. 4 Oct. 2008 (CJM6360); 1 ô, Dunbennan, Huntly, Cemetery, $57.45^{\circ} \mathrm{N}, 2.79^{\circ} \mathrm{W}$, leg. 12 Sep. 2008 (CJM6362); Derbyshire, 13 ex., between Leek and Stoke on Trent (coordinates inaccurate), $53.06^{\circ} \mathrm{N}, 2.12^{\circ} \mathrm{W}$, leg. Sep.1971 (CJM1739) (Martens 1978).

HUNGARY: All Hungarian records of Kolosváry (1963, 1966a, b), Kolosváry \& Homonnay (1967) and Csizmazia et al. (1966) are originally det. as Nelima nigripalpe, of Kolosváry (1965) orig. det. as Nelima glabra and of Kolosváry (1969) orig. det. as Nelima glabra and N. nigripalpe considered as syn. Northern Hungary: Bükk Mts., Bánkút, Veres sár bérc, 48.09 N, 20.49 E, leg. 2 Nov. 2005 (Lengyel \& Murányi 2006 , orig. det. as L. rupestre); Tisza River and surroundings, Kisköre, $47.49^{\circ} \mathrm{N}, 20.51^{\circ} \mathrm{E}$, leg. Aug. 1968 (Kolosváry 1969); 1 ex., Komoró, inundation zone, Salix forest, in humus, $48.31^{\circ} \mathrm{N}, 22.09^{\circ} \mathrm{E}$, leg. 18-31 Jul. 1965 (Kolosváry 1965); Nagyrév, 46.94 N, 20.15 E, leg. Aug. 1968 (Kolosváry 1969); river kilometre 507, „Koldus“ forest near Tiszadob, inundation zone, tree hollows of Salix stem, $48.03^{\circ} \mathrm{N}, 21.18^{\circ} \mathrm{E}$, leg. 18-19+23+31 Jul. 1964 (Csizmazia et al. 1966); many ex. river kilometre 601-602 (near Dombrád), inundation zone, tree hollows of Salix, $48.24^{\circ}$ N, $21.92^{\circ}$ E, leg. 18-31 Jul. 1965 (Kolosváry 1965); river kilometre 602-604 (1-3 km NE Dombrád), inundation zone, at walls of cottage, $48.26^{\circ} \mathrm{N}, 21.94^{\circ} \mathrm{E}$, leg. 18-31 Jul. 1965 (Kolosváry 1965); 1 ex. river kilometre 620, Tuzsér,

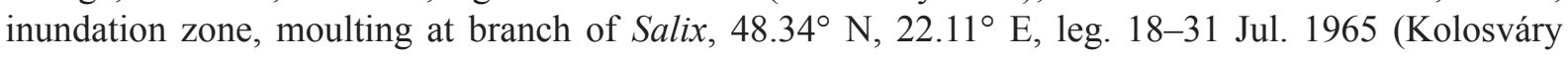


1965); 1 ex., Szabolcsveresmart, inundation zone, Quercus forest, under log, $48.31^{\circ}$ N, $22.02^{\circ}$ E, leg. 18-31 Jul. 1965 (Kolosváry 1965); Tiszabercel, 48.17 N, 21.66 E, leg. Aug. 1968 (Kolosváry 1969); Tiszacsermely, $48.23^{\circ} \mathrm{N}, 21.81^{\circ} \mathrm{E}$, leg. Aug. 1968 (Kolosváry 1969); Tiszadada, inundation zone, listed as terricole species, $48.04^{\circ} \mathrm{N}, 21.24^{\circ} \mathrm{E}$, leg. 1963-1964 (Kolosváry 1966b); 1 ex., Tiszadob, inundation zone, listed as terricole species, $48.03^{\circ} \mathrm{N}, 21.18^{\circ} \mathrm{E}$ (Kolosváry 1963); Tiszaföldvár, $46.99^{\circ} \mathrm{N}, 20.22^{\circ} \mathrm{E}$, leg. Aug. 1968 (Kolosváry 1969); Tiszahát, Endes-Puszta, on Rubus leaves, 48.29 N, 22.23 E, leg. 1 Aug. 1966 (Kolosváry \& Homonnay 1967); Tiszahát, Gergelyiugornya, river kilometre 698, in forest, $48.13^{\circ}$ N, 22.34 E, leg. 27 Jul. 1966 (Kolosváry \& Homonnay 1967); Tiszahát, Gergelyiugornya, river kilometre 698, in forest, skins in tree hollows of Salix and Quercus, $48.13^{\circ}$ N, 22.34 E, leg. 27 Jul. 1966 (Kolosváry \& Homonnay 1967); Tiszahát, Lónya, inundation zone, $48.32^{\circ} \mathrm{N}, 22.25^{\circ} \mathrm{E}$, leg. $21 \mathrm{Jul} .1966$ (Kolosváry \& Homonnay 1967); Tiszahát, Mátyus, on Rubus leaves, $48.29^{\circ} \mathrm{N}, 22.27^{\circ} \mathrm{E}$, leg. $21 \mathrm{Jul}$. 1966 (Kolosváry \& Homonnay 1967); Tiszahát, Tiszamogyorós, in tree hollows, $48.32^{\circ} \mathrm{N}, 22.25^{\circ} \mathrm{E}$,

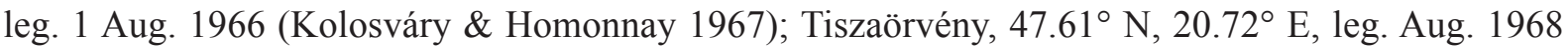

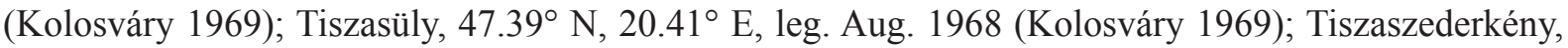
$47.91^{\circ} \mathrm{N}, 21.08^{\circ} \mathrm{E}$, leg. Aug. 1968 (Kolosváry 1969); Tiszatarján, 47.82 N, 21.01 E, leg. Aug. 1968

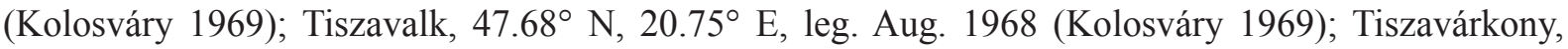

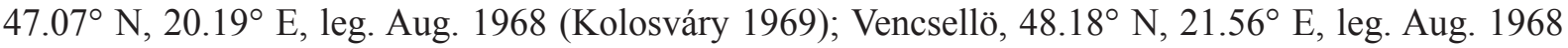
(Kolosváry 1969); Tisza-völgye, Tiszabercel, Babócsa-szög, 48.16 $\mathrm{N}, 21.63^{\circ}$ E, leg. 20 Jul. 2002 (Lengyel \& Muranyi 2006); Tisza-völgye, Tiszabercel, Babócsa-szög, 48.16 N, 21.64 E, leg. $20 \mathrm{Jul}$. 2002 (Lengyel \& Muranyi 2006); Tur River estuary into Tisza River (km 715-744, GPS placed at Tivadar), $48.06^{\circ} \mathrm{N}, 22.52^{\circ} \mathrm{E}$ (Avram 1968, type locality of Leiobunum tisciae); 1 o, 1 क , likely same locality: Tisza River, left banks, leg. 21 Jul. 1967 (CJM3526, det. by Avram, likely part of the type series of Leiobunum tisciae, the remainder of specimens not specified, likely in Bucharest Museum but no data accessible); Zemplén, Erdöhorváti, Tolcsva-patak part, $48.29^{\circ} \mathrm{N}, 21.45^{\circ} \mathrm{E}$, leg. 3.11.2001 (Lengyel \& Muranyi 2006, orig. det. as L. rupestre); Telkibánya, Cserenkö (oberlauf), $48.48^{\circ} \mathrm{N}, 21.35^{\circ} \mathrm{E}$, leg. 30 Sep. 2001 (Lengyel \& Muranyi 2006, orig. det. as L. rupestre).

LATVIA: All Latvian records refer to UNILAT, Spungis 2008, if not otherwise indicated. Aizkraukle Distr., 1 ex., Ërberge, rotten birch wood, $56.37^{\circ}$ N, 25.02 ${ }^{\circ}$ E, leg. 15 Oct. 2006; 1 ex., Koknese, rotten deciduous wood, $56.66^{\circ}$ N, $25.41^{\circ}$ E, leg. 11 Oct. $2003 ; 2$ ex., Krasti, deciduous forest, $56.44^{\circ}$ N, $25.92^{\circ}$ E, leg. 15 Oct. 2006; 1 ex., Vesetas paliene fen, on tree trunk, $56.70^{\circ} \mathrm{N}, 25.81^{\circ} \mathrm{E}$, leg. $15 \mathrm{Jun} .2005 ; 4$ ⿵े $\mathrm{o}^{\circ}$,

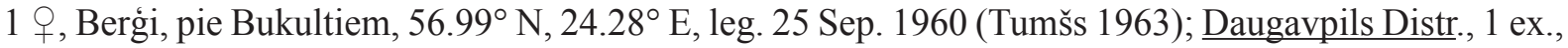
Pilskalnes Siguldiņa, rotten deciduous wood, $55.98^{\circ}$ N, 26.25 E, leg. 15 Oct. 2005; 3 ex., Krāslava

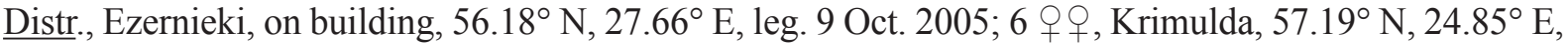
leg. 27 Jul. 1937 (Tumšs 1963); 2 ex., Kuldīga Distr., Īvande, on building, $56.99^{\circ}$ N, $21.76^{\circ}$ E, leg. 22 Oct. 2006; 1 ex., Limbaži Distr., Mērnieki, on wooden building, $57.86^{\circ}$ N, 24.51 ${ }^{\circ}$ E, leg. 14 Aug. 2007; 3 ex., Madona Distr., Bērzaune, on building, $56.81^{\circ} \mathrm{N}, 26.04^{\circ} \mathrm{E}$, leg. 8 Aug. $2007 ; 2 \partial^{\lambda}{ }^{\lambda}$, Moricsala, $57.21^{\circ} \mathrm{N}$, $22.14^{\circ}$ E, leg. 22 Oct. 1960 (Tumšs 1963); Riga Distr., 3 ex., Salaspils, deciduous forest, $56.87^{\circ} \mathrm{N}$, $24.35^{\circ}$ E, 21 Sep. $2005 ; 5$ ex., Tumšupe river valley (GPS not accurate), on white alder trunk, $57.01^{\circ} \mathrm{N}$, $24.61^{\circ}$ E, 22 Aug. 2007; 1 ex., Botanical garden of University of Latvia, greenhouse, pitfall traps, $56.950^{\circ} \mathrm{N}, 24.058^{\circ}$ E, leg. 15-29 Nov. 2004; 1 ex., Dārzinini, on wooden building, $56.87^{\circ} \mathrm{N}, 24.28^{\circ} \mathrm{E}$, leg. 24 Sep. 2006; 4 ex., Nordeķi, deciduous park, 56.96 ${ }^{\circ}$ N, 24.17 E, leg. 24 Sep. 2005 (3 ex.), leg. 5 Oct. 2003 (1 ex.); 9 ex., Saldus Distr., Saldus, Ciecere river valley, on wooden building, $56.67^{\circ} \mathrm{N}$,

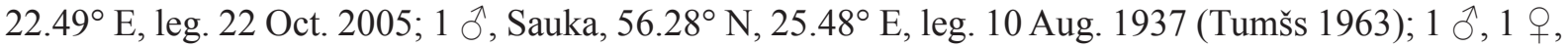

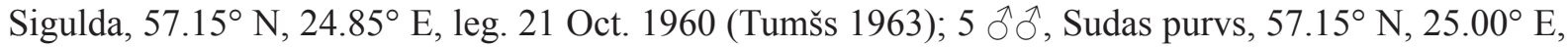
leg. 1 Oct. 1960 (Tumšs 1963); 1 ex., Talsi Distr., Dundaga, deciduous park, $57.51^{\circ} \mathrm{N}, 22.36^{\circ} \mathrm{E}$, leg. 28 Oct.

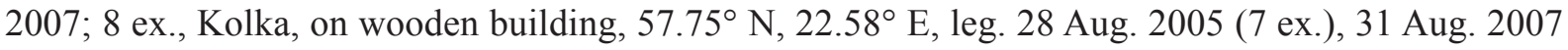

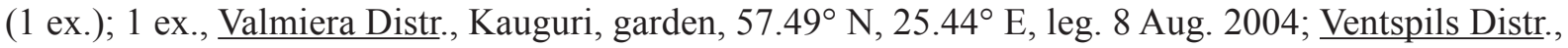
9 ex., Usma, rotten deciduous wood, $57.22^{\circ} \mathrm{N}, 22.15^{\circ}$ E, leg. 13 Aug. 2006. 
NORWAY: Oslo (=Kristiania, coordinates inaccurate), $59.92^{\circ} \mathrm{N}, 10.82^{\circ}$ E, type locality of Leiobunum norvegicum Strand, 1900, 1 क (Strand 1900); 1 \%, 7 juv., Østlandet, Tistedalen, 59.13 ${ }^{\circ} \mathrm{N}, 11.44^{\circ} \mathrm{E}$, leg.

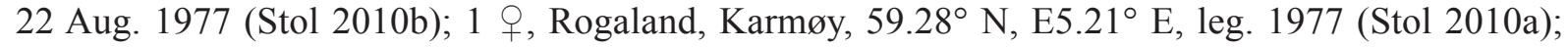
Stavanger, $58.97^{\circ} \mathrm{N}, \mathrm{E} 5.70^{\circ} \mathrm{E}$, leg. ? (SMF, Schönhofer 2005); Vestfold, Botne, 59.482 ${ }^{\circ} \mathrm{N}, 10.275^{\circ} \mathrm{E}$, leg. 13 Sep. 1964 (MBN-A3575, Stol 2010b).

POLAND: 2 juv., Bialowies (no further data, coordinates inaccurate), $52.67^{\circ} \mathrm{N}, 23.83^{\circ} \mathrm{E}$, leg. 15 Aug. 1916 (SMF1603, Müller 1920); 1 ̂, 1 ㅇ, Bieszczady Mts., Distr. Mstrzyki Dolne, Mstrzyki Gorne, "zarošla blehowe" along small stream Terebowiec, 49.10 N, 22.67 E, leg. 25 Sep. 1964 (CJM6368, I.Z.PAN-Warszawa, 35/64); 11 우, 14 juv., Bug River Valley, landscape park N Neple, aggregations under branches close to floor of riverine forest, $100 \mathrm{~m}, 52.135^{\circ} \mathrm{N}, 23.519^{\circ} \mathrm{E}$, leg. $14 \mathrm{Jul} .2010$ (AXLS958); Chylonia (formerly Kielau), $54.53^{\circ} \mathrm{N}, 18.44^{\circ} \mathrm{E}$ (Le Roi 1914); Frombork (formerly Frauenburg), 54.35 ${ }^{\circ} \mathrm{N}, 19.68^{\circ} \mathrm{E}$ (Le Roi 1914); Janów, $53.47^{\circ} \mathrm{N}, 23.23^{\circ} \mathrm{E}$ (Wajgel 1874), orig. Z4612, det. as Leiobunum bicolor); Masurian Lake District, Lidzbark Warmiński, 54.12 ${ }^{\circ} \mathrm{N}, 20.58^{\circ} \mathrm{E}$ (Staręga 1963); 2 웅, 1 juv., Memerki near Wegorzewo, Tilio-Carpinetum, 54.18 ${ }^{\circ} \mathrm{N}, 21.65^{\circ}$ E, leg. 4 Aug. 1983 (SMF36129); Świekatowo (formerly Westpreußen, Johannisberg), $53.42^{\circ} \mathrm{N}, 18.09^{\circ} \mathrm{E}$ (Le Roi 1914); Warschau vicinity (GPS not accurate), $52.21^{\circ} \mathrm{N}, 21.06^{\circ} \mathrm{E}$ (Staręga 1963); Wyżynie Lubelskiej, Kazimierz Dolny, $51.317^{\circ} \mathrm{N}, 21.95^{\circ} \mathrm{E}$ (Staręga 1963).

The following records of Staręga (2004) share the same data: Lysa Gora Mts., different forest communities (Dentario glandulosae-Fagetum, Tilio-Carpinetum, Pino-Quercetum), xerophilic dry grassland, boulders, caves, buildings, leg. Jul. 1981-Aug. 1985. Data differ in: Kakonin, 50.867 N, $20.929^{\circ}$ E; Miejska Gora, $50.957^{\circ} \mathrm{N}, 20.929^{\circ} \mathrm{E}$; NSG Chelmowa Gora, $50.867^{\circ} \mathrm{N}, 21.071^{\circ} \mathrm{E}$; NSG Gora Miedzianka, $50.865^{\circ} \mathrm{N}, 20.361^{\circ} \mathrm{E}$; NSG Milechowy, $50.775^{\circ} \mathrm{N}, 20.362^{\circ} \mathrm{E}$; NSG Skalki Pieklo pod Nieklaniem, $51.226^{\circ} \mathrm{N}, 20.642^{\circ} \mathrm{E}$; NSG Swiety Krzyz, $50.867^{\circ} \mathrm{N}, 21.071^{\circ} \mathrm{E}$; NSG Wykus, $51.047^{\circ} \mathrm{N}$,

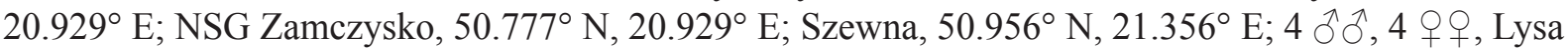
Gora Mts., NSG Lisiny Bodzechowskie, beo Ostrowiec Swietokryskiz, 50.866 ${ }^{\circ}$ N, $21.497^{\circ}$ E, leg. 9 Sep. 1981 (SMF, Staręga 2004); 1 đ̃, 1 ㅇ, Roztoczański National Park, NSG Nart (coordinates inaccur-

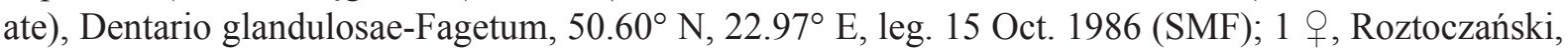
R.N., rez. Bukowa Go'ra FB30, leg. 5 Aug. 1981, subadult (SMF).

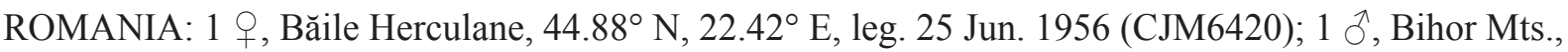
valley around Sighiștel, 46.52 ${ }^{\circ}$ N, 22.54 ${ }^{\circ}$ E, leg. 26 Sep. 1958 (Avram \& Dumitrescu 1969); Bistritz, Dealul Târgului, $47.19^{\circ} \mathrm{N}, 24.50^{\circ} \mathrm{E}$ (Weiss 1996); 2 đô. $^{\circ}$, Cabana Negoiul, $1540 \mathrm{~m}, 45.59^{\circ} \mathrm{N}, 24.52^{\circ} \mathrm{E}$, leg. 24 Jul. 1950 (CJM6426); Fogarasch Mts., Bâlea-Tal, Roter Turm, 45.63 N, 24.26 E (Weiss 1996);

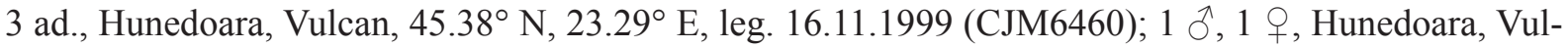

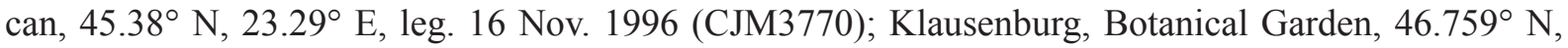

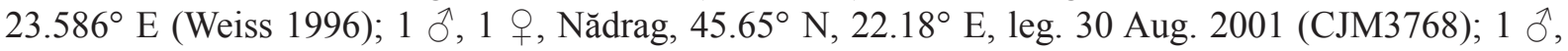

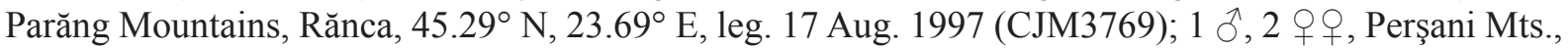

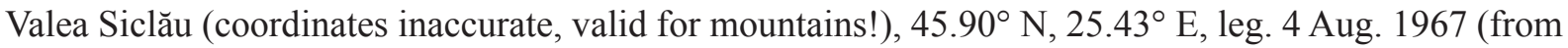

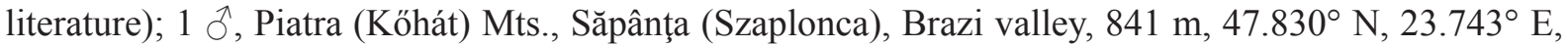
leg. 2 Sep. 2004 (Muranyi \& Lengyel 2006); 8 juv., Piatra (Kőhát) Mts., Săpânţa (Szaplonca), mineral water springs in the lower valley of the Săpânţa (Szaplonca) stream, $408 \mathrm{~m}, 47.9349^{\circ} \mathrm{N}, 23.6781^{\circ} \mathrm{E}$, leg. 30 Jun. 2005 (Muranyi \& Lengyel 2006); 1 juv., Piatra (Kőhát) Mts., Săpânţa (Szaplonca), valley of the Săpânţa (Szaplonca) Stream, 500 m, leg. 30 Jun. 2005 (Muranyi \& Lengyel 2006); 1 Oૈ, Prahova,

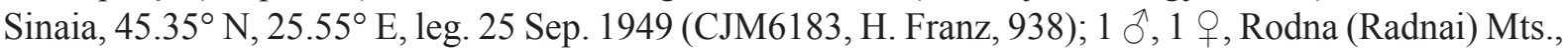
Săcel (Izaszacsal), Iza spring, 900 m, leg. 22 Sep. 2005 (Muranyi \& Lengyel 2006, was described as L. rupestre but doubtful record); 1 §, 1 क , Rodna Mts., Pasul Prislop, 47.609 ${ }^{\circ}$ N, $24.855^{\circ}$ E, leg. 25 Jun. 1968 (Avram \& Dumitrescu 1969); Saschiz, Keisd, 46.194 N, 24.960 E (Weiss 1996); Sebeş Olt (GPS might not be correct), $45.67^{\circ} \mathrm{N}, 24.31^{\circ} \mathrm{E}$ (Weiss 1996); Suceava, Horodnicu de Sus (Russian translation 
and GPS might not be correct), $47.84^{\circ} \mathrm{N}, 25.82^{\circ} \mathrm{E}$ (Cîrdei 1960); Suceava, Măgura Mt. $47.32^{\circ} \mathrm{N}$, $25.96^{\circ}$ E (Roşca 1930); Suceava, Rarău Mt., $47.45^{\circ}$ N, $25.58^{\circ}$ E (Roşca 1930); 2 đ ${ }^{\top}$, Kronstadt, Kapellenberg, $45.635^{\circ} \mathrm{N}, 25.597^{\circ} \mathrm{E}$ (ZMB12634, orig. det. as L. rupestre); $2 \widehat{\partial}^{\widehat{\partial}}$, Sibiu (Hermannstadt), $45.78^{\circ} \mathrm{N}, 24.12^{\circ} \mathrm{E}$, leg. 29 Aug. 1896 (ZMB12636, orig. det. as L. rupestre).

RUSSIA: Oblast St Petersburg (Leningrad), Petrodvorec, $59.886^{\circ} \mathrm{N}, 29.896^{\circ}$ E (Roewer 1957); Primorje (formerly Groß Kuhren), $54.94^{\circ} \mathrm{N}, 20.04^{\circ} \mathrm{E}$ (Le Roi 1914); Rjabinowka (formerly Groß Raum), 54.83

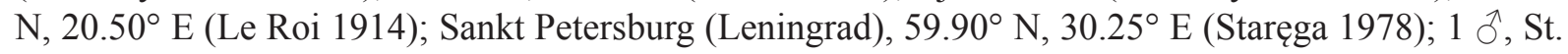

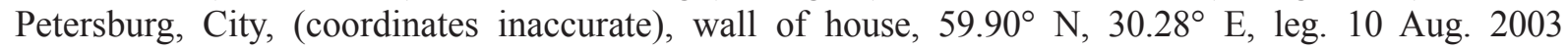

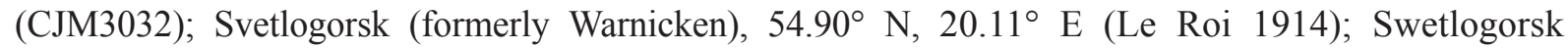

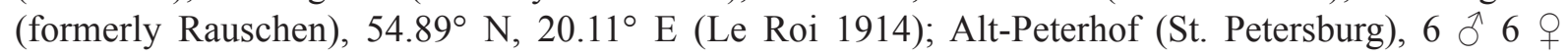
(SMFRII/1201, Roewer 1957).

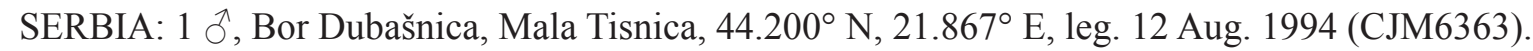

SLOVAK REPUBLIC: Červená skala (Dobšiná), $48.82^{\circ}$ N, 20.13 E (Šilhavý 1981); Dobroč (Brezno nad Hronom), $48.73^{\circ} \mathrm{N}, 19.69^{\circ} \mathrm{E}$ (Šilhavý 1981, all following records from this reference orig. det as L. glabrum); Gornasek (Rožnava; used for GPS), $48.66^{\circ}$ N, $20.54^{\circ}$ E (Šilhavý 1981); Kamenica nad Cir (Kamenica nad Cirochou: GPS), $48.93^{\circ}$ N, $22.00^{\circ}$ E (Šilhavý 1981); Košice, $48.72^{\circ}$ N, $21.25^{\circ}$ E (Šilhavý (1981) did not discriminate betw. L. rupestre and L. tisciae for this record); Nové Mesto nad Váhom, $48.75^{\circ} \mathrm{N}, 17.83^{\circ} \mathrm{E}$ (Šilhavý 1981); Pajštún (Bratislava), $48.27^{\circ} \mathrm{N}, 17.08^{\circ} \mathrm{E}$ (Šilhavý did not discriminate betw. L. rupestre or L. tisciae for this record); Prešov, $48.99^{\circ} \mathrm{N}, 21.24^{\circ} \mathrm{E}$ (Šilhavý (1981) did not discriminate betw. L. rupestre and L. tisciae for this record); Rájecké Teplice, $49.13^{\circ} \mathrm{N}, 18.68^{\circ} \mathrm{E}$ (Šilhavý 1981); Roháče Mts. (coordinates inaccurate), $49.23^{\circ}$ N, $19.72^{\circ}$ E (Šilhavý 1981); Štubnianské Teplice (today Turčianske Teplice), $48.86^{\circ} \mathrm{N}, 18.86^{\circ} \mathrm{E}$ (Šilhavý 1981); Súlov, 49.16 N, $18.59^{\circ} \mathrm{E}$ (Šilhavý 1981); Trenčianske Teplice, $48.91^{\circ} \mathrm{N}, 18.17^{\circ} \mathrm{E}$ (Šilhavý 1981); Vihorlat Mts. (coordinates inaccurate), $48.89^{\circ} \mathrm{N}, 22.13^{\circ} \mathrm{E}$ (Šilhavý 1981); Vrátna dolina (Žilina), $49.26^{\circ} \mathrm{N}, 19.03^{\circ} \mathrm{E}$ (Šilhavý 1981).

SWEDEN: Östergötland (coordinates inaccurate, just for the map!), $58.35^{\circ} \mathrm{N}, 15.51^{\circ} \mathrm{E}$ (Tullgren $1906 \mathrm{a}$, b); Västergötland, Råbäck, $58.61^{\circ} \mathrm{N}, 13.36^{\circ} \mathrm{E}$ (Tullgren 1906a, b); Skåne County, Lund, $55.70^{\circ} \mathrm{N}$, $13.19^{\circ} \mathrm{E}$, leg. Aug. 1872 (Tullgren 1906a, b); Småland (coordinates very inaccurate!), $57.4^{\circ} \mathrm{N}, 15.3^{\circ} \mathrm{E}$ (Tullgren 1906a, b).

UKRAINE: Bez. Černovcy, Ciudei, 48.05 N, 25.62 E, leg. 1935 (Cîrdei 1960); Bez. Kiev, Bila Tserkva (org.: Belaja Cerkov), $49.78^{\circ} \mathrm{N}, 30.13^{\circ} \mathrm{E}$ (Morin 1934); Bez. Užgorod, Rachov, $48.05^{\circ} \mathrm{N}, 24.21^{\circ} \mathrm{E}$

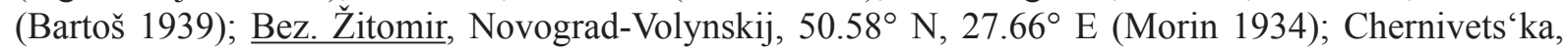
Vijniţa, $48.25^{\circ} \mathrm{N}, 25.19^{\circ} \mathrm{E}$ (Roşca 1930); L'vovskaya oblast' (orig.: Bez. L'vov), Ivano-Frankovo,

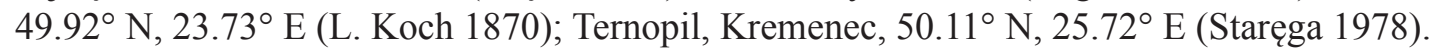

Leiobunum rupestre (Herbst, 1790)

AUSTRIA: Vorarlberg: 1 Oे, Übersaxen, Baschghöhle, 785 m, 47.25 N, 9.67 E, leg. October (Breuss 1995); Salzburg (all records if not otherwise indicated refer to Ausobsky 1987), Bergheim bei Salzburg, Hochgitzen, $47.850^{\circ} \mathrm{N}, 13.034^{\circ} \mathrm{E}$; Buchberg, $47.942^{\circ} \mathrm{N}, 13.092^{\circ} \mathrm{E}$; Haunsberg, $47.92^{\circ} \mathrm{N}, 12.99^{\circ} \mathrm{E}$; Heuberg, $47.82^{\circ} \mathrm{N}, 13.11^{\circ} \mathrm{E}$; Moosachtal bei St. Georgen an der Salzach, $47.98^{\circ} \mathrm{N}, 12.88^{\circ} \mathrm{E}$; Plain, Plainberg, $47.837^{\circ} \mathrm{N}, 13.044^{\circ} \mathrm{E}$; Salzburg, Festungsberg, $47.795^{\circ} \mathrm{N}, 13.048^{\circ} \mathrm{E}$; Salzburg, Kapuzinerberg, $47.803^{\circ} \mathrm{N}, 13.056^{\circ} \mathrm{E}$; Salzburg, Mönchsberg, $47.799^{\circ} \mathrm{N}, 13.039^{\circ} \mathrm{E}$; Salzburger Becken, Elsbethen, Elsbethener Hügel, $47.76^{\circ} \mathrm{N}, 13.10^{\circ} \mathrm{E}$, Georgenberg near Kuchl, 47.635 ${ }^{\circ} \mathrm{N}, 13.161^{\circ} \mathrm{E}$; Hellbrunner Berg, $47.758^{\circ} \mathrm{N}, 13.066^{\circ} \mathrm{E}$; Morzger Hügel, $47.768^{\circ} \mathrm{N}, 13.055^{\circ} \mathrm{E}$; Tannberg, $47.973^{\circ} \mathrm{N}, 13.188^{\circ} \mathrm{E}$; Tiefstein gorge near Schleedorf, $47.947^{\circ} \mathrm{N}, 13.158^{\circ} \mathrm{E}$; Stubachtal, Weissee, $47.16^{\circ} \mathrm{N}, 12.64^{\circ} \mathrm{E}$ (Mazzucco

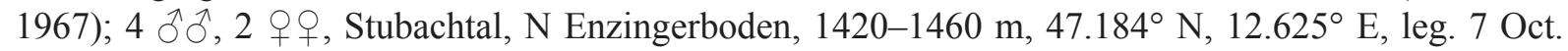


1966 (CJM496); 11 วิธิ, 5 우, Pinzgau, Kaprun, entrance of Sigmund-Thun-Klamm (Alp12_04), 800 $\mathrm{m}, 47.258517^{\circ} \mathrm{N}, 12.738571^{\circ} \mathrm{E}$, leg. 10 Sep. 2012 (AXLS1283); Oberösterreich, Weilhartsforst, $48.16^{\circ}$ $\mathrm{N}, 12.91^{\circ} \mathrm{E}$ (Ausobsky 1987 ); $1 \mathrm{O}^{\top}$, vicinity of Stifterherberge at Bärenstein, 900-950 m, upper coniferous forest, $48.660^{\circ} \mathrm{N}, 13.991^{\circ} \mathrm{E}$ (SMF16343/1); 1 o , Steiermark, Koralpe, Soboth, $900 \mathrm{~m}$, wet slopes near stream, Salix and Abies, 46.67650 N, 15.08331 ${ }^{\circ}$ E, leg. 30 Aug. 2009 (AXLS277); 1 ○, Gesäuse, coniferous forest, $47.58^{\circ} \mathrm{N}, 14.64^{\circ} \mathrm{E}$, leg. 16 Sep. unknown jear (ZMB12640); Kärnten, Baldersdorf, way to Egelsee, $46.78^{\circ} \mathrm{N}, 13.56^{\circ} \mathrm{E}$ (Komposch 2008); Saualpe, Löllingbach, $1100 \mathrm{~m}, 46.55^{\circ} \mathrm{N}, 14.37^{\circ}$ E (Komposch \& Gruber 2004); 5 juv., Flaschberg near Oberdrauburg, $46.75^{\circ}$ N, $12.94^{\circ}$ E, leg. 28 Jul. 1982 (Kofler \& Mildner 1986); Klagenfurt, Sattnitz, boulders betw. Bad and Hanswirt, leg. 3 Sep. 1985 (Kofler \& Mildner 1986); Klagenfurt, Sattnitz, Höllgraben, 46.49 N, $14.28^{\circ}$ E, leg. 10 Sep. 1985 (Kofler

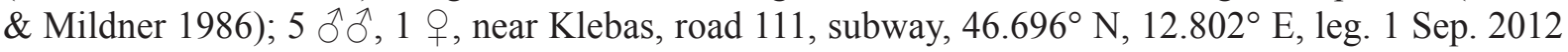
(AXLS1356); Ruin Obertrixen, 46.702 ${ }^{\circ}$ N, $14.575^{\circ}$ E, leg. 19 Aug. 1985 (Kofler \& Mildner 1986); St.

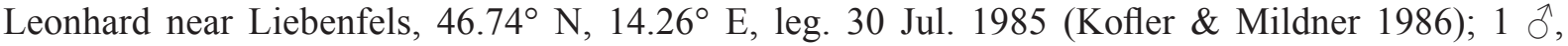
Tröpolach, Gailtal, $900 \mathrm{~m}, 46.62^{\circ} \mathrm{N}, 13.28^{\circ} \mathrm{E}$, leg. 30 Sep. 1975 (CJM1411); Ulrichsberg, 46.71 ${ }^{\circ} \mathrm{N}$,

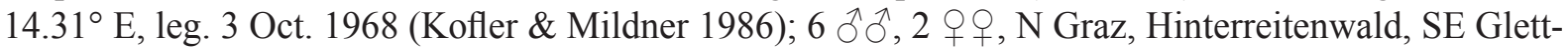
weber, Glettbach, $870 \mathrm{~m}, 47.201^{\circ} \mathrm{N}, 15.428^{\circ} \mathrm{E}$, leg. 14 Sep. 2012 (AXLS1301); Hohe Tauern, Gössnitztal (Gossnitz=Goessnitz), $1700 \mathrm{~m}, 47.031^{\circ} \mathrm{N}, 12.792^{\circ} \mathrm{E}$ (Komposch \& Gruber 1999); Niederösterreich, Lunz am See, forests arround Untersee, $47.85^{\circ} \mathrm{N}, 15.05^{\circ} \mathrm{E}$ (Thaler 1963); 1 ${ }^{\wedge}$, Semmering (M2), $47.63^{\circ} \mathrm{N}, 15.83^{\circ} \mathrm{E}$, leg. Oct. 1899 (ZMB12644); 1 \% , Tirol, Innsbruck, in the city, Weierburggasse, 730-800 m, at housewall, 47.278 $\mathrm{N}, 11.396^{\circ} \mathrm{E}$, leg. 27 Sep.-1 Oct. 1986 (CJM3523); Innsbruck surroundings, Picea forests S of Inn River, Hußlhof-Natters-Amras-Igls-Ampass-Hall, 580 m, in moss (Stipperger 1928); 1 ex., Forellenhof near Lavant, at limestone boulders, $46.79^{\circ} \mathrm{N}, 12.84^{\circ} \mathrm{E}$, leg. $7 \mathrm{Sep}$. 1971 (Kofler 1984); 3 juv., Nikolsdorf, Tal-Trasse, right side of Drau River, $46.78^{\circ} \mathrm{N}, 12.91^{\circ} \mathrm{E}$, leg. 28

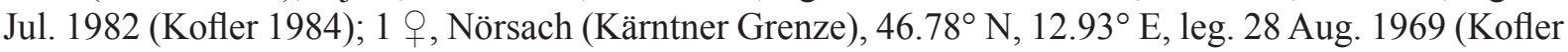
1984); Villgrater Tal (GPS not accurate), $46.80^{\circ} \mathrm{N}, 12.38^{\circ} \mathrm{E}$ (Werner 1931); 1 \% , Virgental, Iselschlucht near Welzelach, $47.017^{\circ} \mathrm{N}, 12.413^{\circ} \mathrm{E}$, leg. 2 Aug. 1978 (Kofler 1984); Windisch-Matrei, 47.00 ${ }^{\circ} \mathrm{N}$, $12.53^{\circ} \mathrm{E}$ (Dalla-Torre 1882); Bärenbadalm above Achensee, $1400-1500 \mathrm{~m}$, caves in Picea forest, $47.42^{\circ} \mathrm{N}$, $11.70^{\circ} \mathrm{E}$ (Stipperger 1928); Hungerburg, $860 \mathrm{~m}$, Sand- and Schotterquarry at border of Picea forest, $47.29^{\circ} \mathrm{N}, 11.40^{\circ} \mathrm{E}$ (Stipperger 1928); Maldontal, betw. Boden and Bschlabs, $1350 \mathrm{~m}$, Fichten- und Föhrenwald, $47.30^{\circ} \mathrm{N}, 10.59^{\circ} \mathrm{E}$ (Stipperger 1928); Stallental, 800-1600 m, Picea forest with Fagus, $47.38^{\circ} \mathrm{N}, 11.69^{\circ} \mathrm{E}$ (Stipperger 1928); Kaunertal from Kaltenbrunn and Feuchten to Gepatschhaus (coordinates inaccurate), 1260-1700 m, Picea forest, humid cliffs along stream and path, $47.05^{\circ} \mathrm{N}$, $10.75^{\circ} \mathrm{E}$ (Stipperger 1928); Oberbergtal from Milders im Stubai to Stöcklenalm (coordinates inaccurate), $1100-1600 \mathrm{~m}$, Picea forest, at boulders, $47.12^{\circ} \mathrm{N}, 11.32^{\circ} \mathrm{E}$ (Stipperger 1928); S St. Anton am Arlberg, 1310 m, cliffs in Picea forest, $47.13^{\circ}$ N, $10.27^{\circ}$ E (Stipperger 1928); Schwaz, betw. Schloß Freundsberg and Rodlhütte, 540-1600 m, Picea forest mixed with Abies and Fagus, under leaf litter, in moss, at stones and truncs, $47.34^{\circ} \mathrm{N}, 11.71^{\circ} \mathrm{E}$ (Stipperger 1928); Sellraintal betw. Kematen, Gries and Praxmar, 610-1600 m, humid, shaded cliffs and moss at stream in Picea forest, $47.17^{\circ} \mathrm{N}, 11.14^{\circ} \mathrm{E}$ (Stipperger 1928); between Pettneu and Malfontal, 1200-1300 m, Picea forest, $47.140^{\circ} \mathrm{N}, 10.343^{\circ} \mathrm{E}$ (Stipperger 1928); betw. Volders and Volderer Wildbad, 600-1100 m, wet Picea forest with Alnus; 3 ôे $\hat{0}, 47.27^{\circ} \mathrm{N}$, $11.56^{\circ} \mathrm{E}$ (Stipperger 1928); Lienz (GPS not accurate), $46.83^{\circ} \mathrm{N}, 12.76^{\circ} \mathrm{E}$, (SMFRII/1184, Roewer

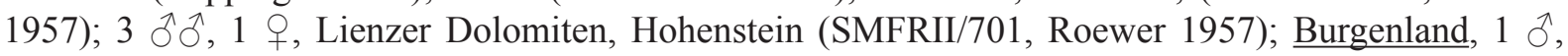
southern Leithagebirge, „Kürschnergrube” (abandoned chalk quarry) $\mathrm{N}$ of Eisenstadt, $435 \mathrm{~m}$, in man made cavity at steep humid cliff, $47.86^{\circ} \mathrm{N}, 16.52^{\circ} \mathrm{E}$, leg. 7 Nov. 1996 (NMW17922, Gruber 2000).

BOSNIA AND HERZEGOVINA: 11 $\widehat{\partial}, 1$, , Jaice (=Jajce), tufa walls, waterfall, $44.342^{\circ} \mathrm{N}, 17.266^{\circ} \mathrm{E}$

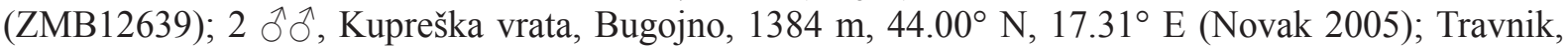

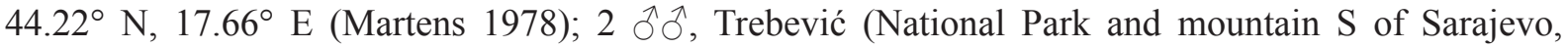
coordinates accurate), Corylus forest, $43.8^{\circ} \mathrm{N}, 18.45^{\circ} \mathrm{E}$, leg. Sep.-Oct. (ZMB12638); 4 ô $\mathrm{o}^{\mathrm{N}}, 1$ juv., Vilinska jama cave, $42.73^{\circ} \mathrm{N}, 17.89^{\circ} \mathrm{E}$, leg. 1916 (Novak 2005). 


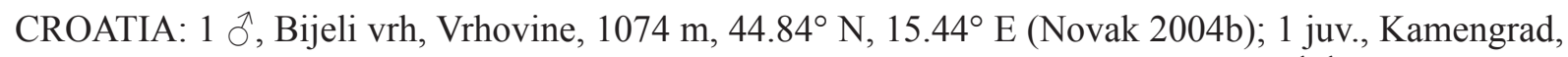
Papuk Mt., beside the Orljava river, $528 \mathrm{~m}, 45.53^{\circ} \mathrm{N}, 17.50^{\circ} \mathrm{E}$ (Novak 2004b); $5 \delta^{\top} \delta^{\top}, 2$ 우, 2 juv., Kamenica Skradnička, beside the Rudnica brook (WL30), $260 \mathrm{~m}, 45.20^{\circ} \mathrm{N}, 15.45^{\circ} \mathrm{E}$, leg. May 1985

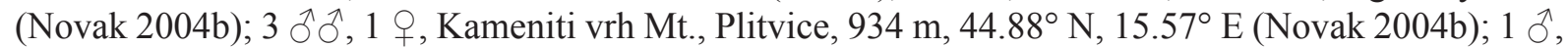

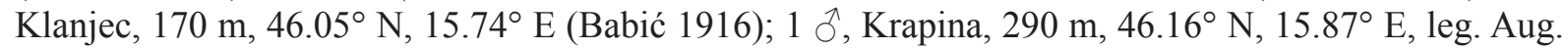
1914 (Babić 1916); Križevci, 140 m, $46.03^{\circ} \mathrm{N}, 16.52^{\circ} \mathrm{E}$ (Daday 1896), orig. det. as Liobunum glabrum);

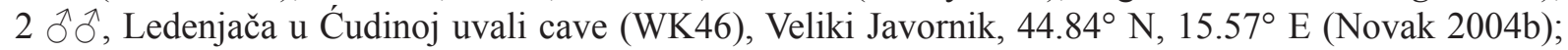
Maksimova pećina cave, Jankovac, $657 \mathrm{~m}, 45.52^{\circ} \mathrm{N}, 17.68^{\circ} \mathrm{E}$ (Babić 1916); 2 ồ, Medveđak Mt.,

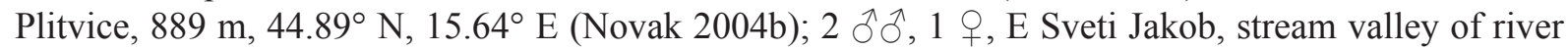
Medvešćak, $600 \mathrm{~m}$, under stones and wet $\operatorname{logs}$ near river, $45.884^{\circ} \mathrm{N}, 15.945^{\circ} \mathrm{E}$, leg. 9 Sep. 2009 (AXLS345); 1 juv., near Vrilo Rudnice, Kamenica Skradnička, 260 m, 45.23 N, 15.35 E, leg. Jul. 1987 (Novak 2004b); 1 juv., Ozalj, Karlovac, Kordun, Ozaljska spilja cave, $45.62^{\circ}$ N, $15.45^{\circ}$ E, leg. 6378 (Novak 2004b); 13 juv., Pećina pri Tržiću (=Pećina kod mlina), Tržić Tounjski, beside the Mrežnica

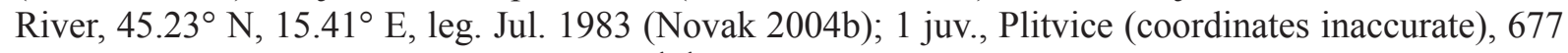

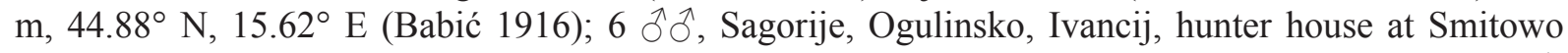
jezero, $351 \mathrm{~m}$, at large rocks in Fagus forest, $45.188^{\circ} \mathrm{N}, 15.223^{\circ}$ E, leg. 7 Sep. 2009 (AXLS319); 1 ठै, 1 + , Sagorije, Ogulinsko, Ivancij, Sagorska peč, $326 \mathrm{~m}$, at wall in cave entrance, $45.197^{\circ} \mathrm{N}, 15.222^{\circ} \mathrm{E}$,

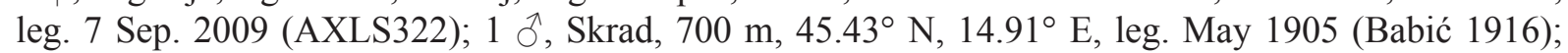
1 juv., Sveta gora, $580 \mathrm{~m}, 45.53^{\circ} \mathrm{N}, 14.67^{\circ} \mathrm{E}$ (Novak 2004b, Babić det. as O. alpinus); 1 ग, 1 O, Vilinska jama cave (=Vilina jama, Volina-Volinjska jama, one hour away from Krapina), leg. 11 Aug. 1885 (Jurinac 1886, Novak 2004b), orig. det. as Liobunum religiosum).

CZECH REPUBLIC: All records originate from Šilhavý (1981) so far not otherwise indicated. Šumava, Boubín, $48.94^{\circ} \mathrm{N}, 13.79^{\circ} \mathrm{E}$; Holná (maybe wrong), $49.12^{\circ} \mathrm{N}, 14.87^{\circ} \mathrm{E}$; Horní Smrěné, $49.33^{\circ} \mathrm{N}, 15.76^{\circ}$ E; Hrubá Skála, $50.54^{\circ} \mathrm{N}, 15.19^{\circ} \mathrm{E}$; Ještěd Mt., $50.73^{\circ} \mathrm{N}, 14.98^{\circ} \mathrm{E}$; Jevany, $49.97^{\circ} \mathrm{N}, 14.81^{\circ} \mathrm{E}$ (Šilhavý

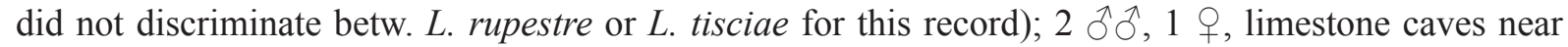
Brünn (Brno), leg. 17 Sep. 1971 (CJM982); Klučky (mountain ridge near Nový Bor), 50.78 N, 14.50 E; Koněšín, $49.19^{\circ} \mathrm{N}, 16.04^{\circ} \mathrm{E}$; Kunratice, $50.01^{\circ} \mathrm{N}, 14.48^{\circ} \mathrm{E}$ (Šilhavý did not discriminate betw. L. rupestre or L. tisciae for this record); Kvilda, $49.02^{\circ} \mathrm{N}, 13.58^{\circ} \mathrm{E}$; Lamberk (Náměšt' nad Oslavou), $49.17^{\circ} \mathrm{N}, 16.18^{\circ} \mathrm{E}$; Máchovo jezero (Dosky), $50.58^{\circ} \mathrm{N}, 14.67^{\circ} \mathrm{E}$; Mariánské Lázně, $49.96^{\circ} \mathrm{N}, 12.70^{\circ}$ E; Mohelno (Třebíč), $49.11^{\circ} \mathrm{N}, 16.19^{\circ} \mathrm{E}$; Moravský kras, $49.31^{\circ} \mathrm{N}, 16.70^{\circ} \mathrm{E}$; Olší (Jindřichův Hradec), $49.16^{\circ} \mathrm{N}, 15.37^{\circ} \mathrm{E}$; Pravčická brána (Hřensko), $50.88^{\circ} \mathrm{N}, 14.28^{\circ} \mathrm{E}$; Rokytnice nad Jizerou, $50.73^{\circ} \mathrm{N}$, $15.45^{\circ}$ E; Rýchory, $50.67^{\circ} \mathrm{N}, 15.87^{\circ} \mathrm{E}$; Špindleruv Mlýn, $50.73^{\circ} \mathrm{N}, 15.61^{\circ} \mathrm{E}$; Tiské skály (Děčín), $50.80^{\circ} \mathrm{N}, 14.04^{\circ} \mathrm{E}$; Tremšín (Rožmitál), $49.57^{\circ} \mathrm{N}, 13.78^{\circ} \mathrm{E}$ (Šilhavý did not discriminate betw. L. rupestre or L. tisciae for this record); Vlčí kopec, $49.15^{\circ} \mathrm{N}, 16.45^{\circ} \mathrm{E}$.

GERMANY: Baden-Württemberg, 2 q, , Nature Reserve Wutachschlucht, Stigelesfels, $48.0166^{\circ} \mathrm{N}$,

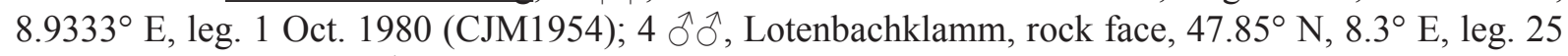
Jul. 1964 (CJM123); 1 § , Schwäbische Alb, Höllochschacht bei Dettingen, $48.513^{\circ} \mathrm{N}, 9.346^{\circ} \mathrm{E}$, leg.

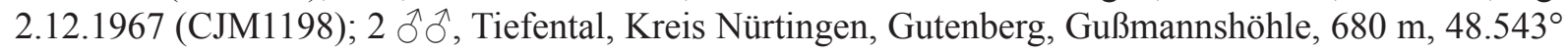

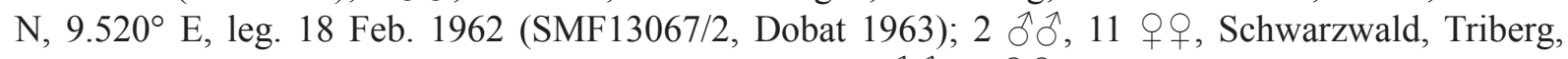
$48.13^{\circ} \mathrm{N}, 8.23^{\circ}$ E, leg. Aug. 1959 (SMF11173/12); 5 đô, 3 우, S-Schwarzwald, Schwarzatal S Schluchsee, Schwarzahalden, 600 m, Bannwald, 47.74 N, 8.19 E, leg. 14 Sep. 2008 (CJM6207); 2

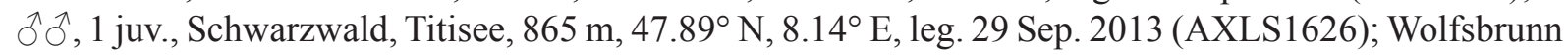
near Heidelberg, $49.412^{\circ}$ N, $8.746^{\circ}$ E (C. Koch 1871; Le Roi 1914); Bayern, Benediktenwand, $47.65^{\circ}$ $\mathrm{N}, 11.47^{\circ} \mathrm{E}$ (L. Koch 1861); Berchtesgaden, Jenner, $800 \mathrm{~m}$, forest, $47.58^{\circ} \mathrm{N}, 13.00^{\circ} \mathrm{E}$ (Hammelbacher 1986); 1 今 , 1 क , Ramsau / Wachterl, $1000 \mathrm{~m}$, mixed forest, $47.65^{\circ} \mathrm{N}, 12.866^{\circ} \mathrm{E}$, leg. $11 \mathrm{Jul} .1986$ (CJM2804); 3 गे $\hat{\sigma}^{2}$, Tegernsee, ascend to Wallberg, 700-1000 m, coniferous forest, at cliff, $47.68^{\circ} \mathrm{N}$, $11.75^{\circ} \mathrm{E}$, leg. 31 Sep. 2006 (CJM5318); near Regensburg (GPS for the city), $48.97^{\circ} \mathrm{N}, 12.13^{\circ} \mathrm{E}$ (Martens 1978); 4 ơ $\partial^{\lambda}$, Bavarian Forest, N Finsternau, Siebensteinkopf, $1130-1200 \mathrm{~m}, 48.95^{\circ} \mathrm{N}, 13.566^{\circ} \mathrm{E}$, leg.

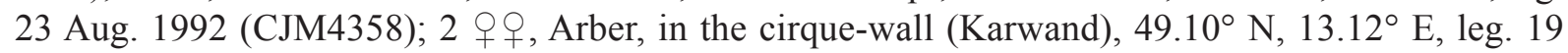


Aug. 1964 (CJM136); 20 juv., Lusen, Arber, Riesloch Falls, 48.933 N, 13.50 E, leg. 14-17 Aug. 1964

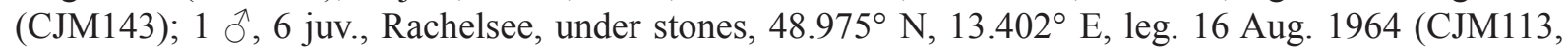

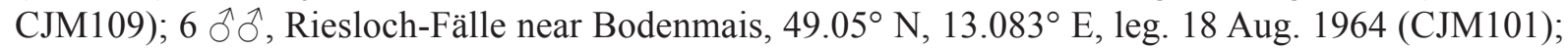
1 ô, 1 o, Garmisch-Partenkirchen, Partnachklamm, 850 m, $47.466^{\circ} \mathrm{N}, 11.116^{\circ} \mathrm{E}$, leg. 14 Oct. 1978

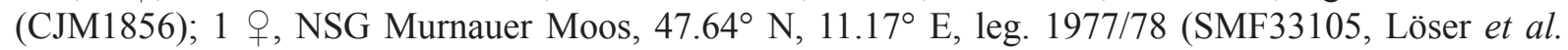
1982); Nürnberg, betw. Bruck and Happburg (coordinates inaccurate), $49.52^{\circ} \mathrm{N}, 11.18^{\circ} \mathrm{E}$ (L. Koch 1877, as L. bicolor); Pottenstein, Fränkische Schweiz, $49.77^{\circ}$ N, $11.40^{\circ}$ E, leg. 1 Oct. 1948 (SMF59294,

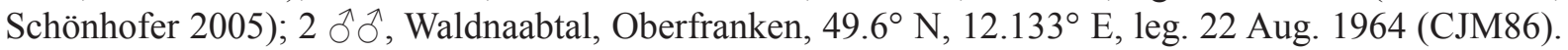
Hessen, 1 \% , Werra-Meißner-Kreis, Meißner, stone cellar near Neuen Schwalbenthaler Erbstollen (No. 4725/58), 580 m, Mittlerer Buntsandstein, 51.2056 N, $9.8709^{\circ}$ E, leg. 25 Oct. 2005 (CJM4802, S. Zänker, WK 211); Thüringen, $2{ }^{\AA} \partial^{\AA}$, Schwarza Valley near Schwarzburg, $50.633^{\circ} \mathrm{N}, 11.183^{\circ} \mathrm{E}$, leg. 28 Sep. 2006 (CJM5392); Sachsen, 1 , Erzgebirge (Ore Mountains), at Floßgraben betw. Aue and Bockau, $50.55^{\circ} \mathrm{N}, 12.67^{\circ} \mathrm{E}$, leg. 21 Nov. 1926 (Büttner 1930); Lausitzer Mts., Neiße Valley betw. Östritz and

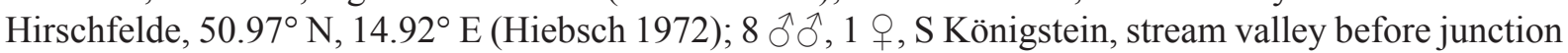
to Cunnersdorf, Biela Stream, $150 \mathrm{~m}$, at stone bridge, 50.903 ${ }^{\circ} \mathrm{N}, 14.064^{\circ}$ E, leg. 9 Sep. 2006 (CJM5293); $7 \widehat{\jmath} \widehat{\jmath}$, Schöna, near border to Czech Republic, $100 \mathrm{~m}$, coniferous and mixed forest, at night at wood and stones, $50.867^{\circ} \mathrm{N}, 14.217^{\circ} \mathrm{E}$, leg. 13 Oct. 2005 (CJM4752); 2 우, same data (CJM4753).

HUNGARY: Budapest, Mecsek Mts. (coordinates inaccurate), 47.51 N, $19.01^{\circ}$ E (Kolosváry 1929, 1964); 10 ex., Geschriebenstein Nature Park, beside road to Velem (St. Veit), NNE Óház, WSW Köszeg (Güns), $400 \mathrm{~m}$, scree in a fresh deciduous forest with maple, linden, hombeam and beech, $47.22^{\circ} \mathrm{N}$, $16.30^{\circ} \mathrm{E}$ (Komposch 2004); Köszegi-hegység, Köszeg, Hét-forrás, $47.39^{\circ} \mathrm{N}, 16.53^{\circ} \mathrm{E}$, leg. 31 Aug. 2005 (Lengyel \& Muranyi 2006); Köszegi-hegység, Velem, Szerdahelyi-patak-part, $47.345^{\circ} \mathrm{N}, 16.514^{\circ} \mathrm{E}$, leg. 17 Sep. 2005 (Lengyel \& Muranyi 2006).

ITALY: Carnia, $46.37^{\circ} \mathrm{N}, 13.14^{\circ} \mathrm{E}$ (Caporiacco 1922); 1 ○े, Friuli-Venezia Giulia, Prov. Udine, Carnic Alps near Tarvisio, $800 \mathrm{~m}, 46.50^{\circ} \mathrm{N}, 13.57^{\circ} \mathrm{E}$, leg. 1 Oct. 1975 (CJM1456); 2 juv., Moggio Udinese, Stavoli Cuel Lung alto, Mt. Zovet (UM53), $700 \mathrm{~m}$, Fagetum, pitfall traps, $46.48^{\circ} \mathrm{N}, 13.19^{\circ} \mathrm{E}$, leg. $16 \mathrm{Jul}$. -20 Aug. 2001 (MFSNU, Novak 2004a); 1 ऽ, SE Arta Therme, path in forest, $46.478^{\circ} \mathrm{N}, 13.069^{\circ} \mathrm{E}$, leg. 1 Sep. 2012 (AXLS1349); 1 , Resia, above Clen, between Casera Coot and Slatina superiore (UM73), 1000 m, Fagetum, pitfall traps, leg. 20 Aug.-26 Sep. 2001 (MFSNU, Novak 2004a); 3 juv., Resia, between Berdo di Sopra and Rio Malidul (UM73), 1260 m, 46.34 ${ }^{\circ}$ N, $13.29^{\circ}$ E, leg. 12 Jun. 2003 (MFSNU, Novak 2004a); Südtirol, Meran, $46.68^{\circ} \mathrm{N}, 11.17^{\circ} \mathrm{E}$ (L.Koch 1869 , type locality of Leiobunum glabrum L. Koch, 1869).

POLAND: 3 $\lesssim$ , Kitz....? (maybe Kitzelberg; label not legible) Bober Katzbach Mts. (GPS not accurate), 50.96 N, 15.84 E, leg. 6 Sep. 1924 (ZMB12643). Karkonosze Mts. (Staręga 2004).

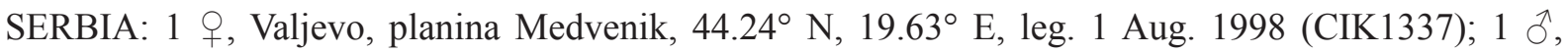
Valjevo, planina Medvenik, Drenaička pecina, leg. 20 Oct. 1999 (CIK1336).

SLOVENIA: Alto Isonzo, Monte Merzlì, $46.22^{\circ} \mathrm{N}, 13.70^{\circ} \mathrm{E}$, leg. Nov. 1915 (Marcellino 1973); 1 đ, Celje (Cilli), deciduous forest, $46.24^{\circ} \mathrm{N}, 15.26^{\circ} \mathrm{E}$, leg. 25 Oct. (ZMB12635); $7 \AA^{\lambda}$, Huda Luknaja Cave, Tisnick Mt. SE Slowenj Gradec, $46.48^{\circ}$ N, $15.07^{\circ}$ E, leg. 16 Oct. 2004 (CJM4203); 3 q , , Huda Luknaja Cave, Tisnick Mt., SE Slowenj Gradec (GPS S of city), $46.48^{\circ}$ N, $15.07^{\circ}$ E, leg. 16 Oct. 2004 (CJM4204); $15 \widehat{\partial} \partial^{2}, 4$ 우, Julian Alps, road to Mount Mangert, upper end of village Strmec na Predelu, $1013 \mathrm{~m}$, $46.41769^{\circ} \mathrm{N}, 13.60833^{\circ}$ E, leg. 28 Aug. 2009 (AXLS264); 4 § ${ }^{\lambda}$, Karawanken, road to Loibl Pass, $650 \mathrm{~m}, 46.40^{\circ} \mathrm{N}, 14.28^{\circ} \mathrm{E}$, leg. 2 Oct. 1975 (CJM1445); 6 o ${ }^{\circ}, 1$ q, Ljubljana, small forest at northern

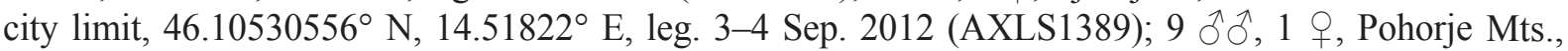
Mislinja, locality Glažuta, $1013 \mathrm{~m}$, stream valley, on cliff-faces in coniferous forest, $46.480^{\circ} \mathrm{N}$,

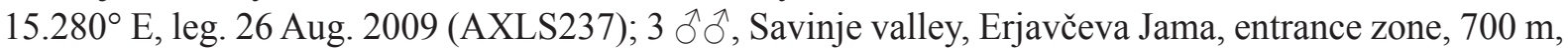


$46.383^{\circ} \mathrm{N}, 14.717^{\circ} \mathrm{E}$, leg. 2 Oct. 1994 (CJM3161); 1 ㅇ, Slowenj Gradec, at housewall, $46.51^{\circ} \mathrm{N}$,

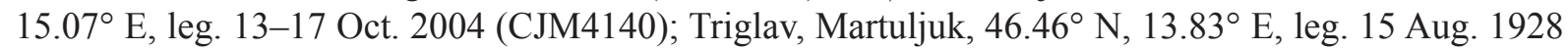
(Hadži 1931); 1 juv., vicinity of Zirknitz (=Cerknica), $650 \mathrm{~m}$, Fagus forest, $45.79^{\circ} \mathrm{N}, 14.37^{\circ} \mathrm{E}$, leg. $17 \mathrm{Jul}$. 1974 (CJM1260); 3 సै ${ }^{\lambda}, 1$ ㅇ, Unec, Rakov Škocjan, at border of river Rak, 520 m, at cliff in Fagus

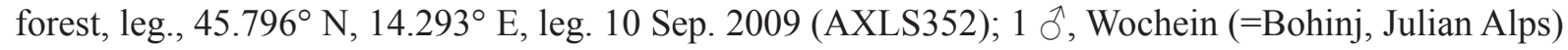
(ZMB12637).

SWITZERLAND: Basel-Landschaft, Arlesheim, $47.49^{\circ}$ N, $7.63^{\circ}$ E (Müller \& Schenkel 1895; Lessert 1917). 